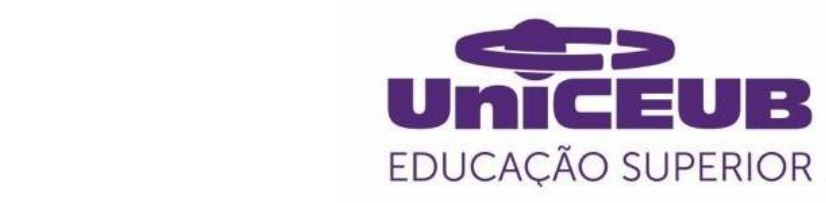

CENTRO UNIVERSITÁRIO DE BRASÍLIA- UniCEUB PROGRAMA DE INICIAÇÃO CIENTÍFICA

AMANDA CINTRA SANTOS

A ARQUITETURA VERNACULAR E SEU POTENCIAL DE USO EM PROJETOS SOCIAIS

BRASÍLIA 2020 


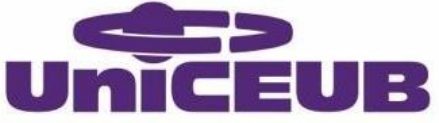

EDUCACุÃO SUPERIOR

AMANDA CINTRA SANTOS

\section{A ARQUITETURA VERNACULAR E SEU POTENCIAL DE USO EM PROJETOS SOCIAIS}

Relatório final de pesquisa de Iniciação Científica apresentado à Assessoria de Pós-Graduação e Pesquisa.

Orientação: Gustavo Cantuária

\section{BRASÍLIA}




\section{DEDICATÓRIA}

Dedico essa pesquisa ao meu avô, Mucio Barreto Cintra, homem de origem simples que construiu seu mundo com terra, sangue e suor. 


\section{EPÍGRAFE}

"Mas é claro também que, enquanto a ligação entre os arquitetos e as massas populares não se estabelecer, não se organizar, enquanto a obra dos arquitetos não tiver a suma glória de ser discutida nas fábricas e nas fazendas, não haverá arquitetura popular". (Artigas, 1981) 


\section{RESUMO}

A sociedade atual se encontra em um período de transformação de conceitos, o próprio conceito de tecnologia vem sendo modificado. Ao contrário do otimismo cego presente durante a revolução industrial, quando acreditava-se que a salvação do mundo decorreria da exploração desmedida da natureza para alimentar a completa automatização do trabalho, o conceito de tecnologia atual está intrinsicamente conectado ao conceito de sustentabilidade de forma que o primeiro só é eficiente caso não represente um retrocesso nas conquistas realizadas pelo segundo. $\mathrm{Na}$ arquitetura não poderia ser diferente, as abordagens ecológicas no espaço arquitetônico passaram a ser de suma importância para uma construção eficiente. A pesquisa em questão busca explorar a potencialidade da arquitetura vernacular aplicada a questão da habitação de interesse social. Para elaboração desse trabalho em questão foi realizada uma revisão bibliográfica extensa para entender melhor a origem da tipologia arquitetura popular e arquitetura social, foi pesquisado também a aplicabilidade da arquitetura vernacular de acordo com as normas de construção do Brasil e o desempenho técnico dessa tipologia comparado com os métodos de construção tradicionais. Para a confirmação da tese foram feitas medições em loco em duas moradias, uma referente ao programa Minha Casa Minha Vida e outra a uma casa centenária de Pau-a-Pique, essa tipologias foram comparadas a respeito da durabilidade, manutenção, conforto térmico, engajamento social, e valor de construção. Pode- se concluir que a arquitetura vernácula possui uma superioridade significativa na maioria dos aspectos comparados e portanto é uma alternativa válida e ideal para a elaboração de programas de assistência social.

Palavras-Chave: Arquitetura Vernacular. Arquitetura Popular. Projetos sociais. Assistência a Moradia. Déficit Habitacional. 


\section{LISTAS DE FIGURAS}

Figura 1- Batente da porta indicando o ano de construção. (Fonte: Própria)

Figura 2- Fachada frontal encoberta por um beiral de mais de 5M. (Fonte: Própria)

Figura 3- Fachada frontal encoberta por um beiral de mais de $5 \mathrm{M}$, foto termográfica. (Fonte: Própria)

Figura 3- Parede interna em frente a fachada frontal. (Fonte: Própria)

Figura 4- Parede interna em frente a fachada frontal, foto termográfica. (Fonte: Própria)

Figura 5- Parte externa da parede posterior. (Fonte: Própria)

Figura 6- Parte externa da parede posterior, foto termográfica. (Fonte: Própria)

Figura 7- Parte interna da parede posterior. (Fonte: Própria)

Figura 8- Parte interna da parede posterior, foto termográfica. (Fonte: Própria)

Figura 9- Parte externa da parede lateral. (Fonte: Própria)

Figura 10- Parte externa da parede lateral, foto termográfica. (Fonte: Própria)

Figura 11- Parte interna da parede lateral. (Fonte: Própria)

Figura 12 - Parte interna da parede lateral, foto termográfica. (Fonte: Própria)

Figura 13- Parte interna da parede lateral em um cômodo sem abertura de esquadria nessa orientação. (Fonte: Própria)

Figura 14- Parte interna da parede lateral em um cômodo sem abertura de esquadria nessa orientação, foto termográfica. (Fonte: Própria) 


\section{LISTAS DE TABELAS}

Tabela 1 - Comparação das emissões de dióxido de carbono (CO2) na produção de paredes de diversos materiais construtivos. (Fonte: BESTRATEN, 2011; Tradução, MARQUES, 2018)

Tabela 2 - Comparação das emissões de dióxido de carbono (CO2) na produção de paredes de diversos materiais construtivos. (Fonte: MARQUES, 2018 com base nas fontes especificadas na tabela)

Tabela 3- Resultados de transmitância e capacidade térmica dos cenários $A 1$ e $C 1$. (Fonte: PIRE E BRAGA,2018) 


\section{LISTAS DE GRÁFICOS}

Gráfico 1- A relação entre o déficit habitacional e moradias construídas pelo programa Minha Casa Minha Vida (Fonte:http://www.seduh.df.gov.br/wpconteudo/uploads/2017/10/diagnóstico_preliminar_plandhis.pdf)

Gráfico 2- Temperatura e zona de conforto em todas as estações em Brasília/DF. (Fonte: Projeteee, 2020)

Gráfico 3- Condições de conforto em todas as estações em Brasília/DF. (Fonte: Projeteee, 2020) 


\section{SUMÁRIO}

INTRODUÇÃO.

FUNDAMENTAÇÃO TEÓRICA

METODOLOGIA

1 A HABITAÇÃO DE INTERESSE SOCIAL

1.1 INTRODUÇÃO

1.2 CONTEXTUALIZAÇÃO.

1.3 HABITAÇÃO DE INTERESSE SOCIAL NO BRASIL

1.4 HABITAÇÃO DE INTERESSE SOCIAL NO DISTRITO FEDERAL

2 SOBRE ARQUITETURA PPOPULAR COM TERRA CRUA

2.1 INTRUDUÇÃO

2.2 ADOBE

2.2.1. CONCEITO

2.2.2. ENGAJAMENTO SOCIAL

2.2.3 COMPORTAMENTO TERMICO DO MATERIAL

3. COMPATIBILIDADE COM A NORMA

4 AFERIÇÃO DE DADOS EM LOCO

5 ENTREVISTAS

5.1 ENTREVISTA COM MORADORES

DE ARQUITETURA VERNACULAR

5.2 ENTREVISTA COM MORADORES

DO PROGRAMA MINHA CASA MINHA VIDA

CONCLUSÕES FINAIS

REFERÊNCIAS 


\section{INTRODUÇÃO}

A sociedade atual se encontra em um período de transformação de conceitos, o próprio conceito de tecnologia vem sendo modificado. Ao contrário do otimismo cego presente durante a revolução industrial, quando acreditava-se que a salvação do mundo decorreria da exploração desmedida da natureza para alimentar a completa automatização do trabalho, o conceito de tecnologia atual está intrinsicamente conectado ao conceito de sustentabilidade de forma que o primeiro só é eficiente caso não represente um retrocesso nas conquistas realizadas pelo segundo.

$\mathrm{Na}$ arquitetura não poderia ser diferente, as abordagens ecológicas no espaço arquitetônico passaram a ser de suma importância para uma construção eficiente. Nesse contexto uma construção sustentável é aquela que possui os materiais e os processos construtivos de menor impacto ambiental, e que garanta a qualidade e 0 conforto aos seus usuários (ROCHETA; FARINHA, 2007; ARAÚJO, 2012). Para a realização de uma construção sustentável é essencial o uso de tecnologias, sejam essas no âmbito de materiais novos ou até mesmo no reavivamento de materiais tradicionais usados de forma inovadora.

A arquitetura vernacular por si só é um excelente exemplo de tecnologias construtivas tradicionais utilizadas de forma inovadora. A respeito dessa tipologia arquitetônica o escritor e pesquisador Günter Weimer enumerou seis características principais que demonstram a potencialidade dessa arquitetura. Essas características são:

- A simplicidade, por conta da utilização de recursos naturais locais.

- A adaptabilidade, por ser um registro de técnicas exógenas adaptadas ao clima e materiais nacionais.

- A auto explicação, sua forma plástica é resultado dos materiais e das técnicas utilizadas.

- A hereditariedade de tradições, por ser resultado de uma evolução multissecular e de profundo respeito com as tradições culturais passadas de pais para filhos. 
- A permeabilidade às contingências sociais, pois tem uma grande capacidade de adaptação as diversas fases da sociedade

- A criatividade, por conta da capacidade de cumprir as demais características.

Como evidenciado nos itens acima a arquitetura popular, como é chamada a vertente vernacular por alguns autores, possui muitas características que condissem com o pensamento atual de sustentabilidade e ao mesmo tempo é uma técnica que se encontra ao alcance da população brasileira com menor poderio econômico o que faz dela uma boa opção construtiva para ser implementada em programas de assistência a moradia como o minha casa minha vida ou até mesmo para o desenvolvimento de novos programas nos quais a própria população pode ser um agente ativo na transformação da paisagem urbana.

Historicamente o conforto térmico e eficiência energética no Brasil são diretamente associados ao alto custo de materiais e elementos construtivos, por conta disso a habitação de interesse social tem apresentado problemas de adequação climática (GRIGOLETTI; ROTTA; MÜLLER, 2010) contudo as construções vernáculas com terra crua possuem alto desempenho térmico além de estarem relacionadas à sustentabilidade econômica, sustentabilidade ecológica e sustentabilidade social (REIS, 2010).

Portanto torna-se objeto dessa pesquisa a verificar a viabilidade da implantação da arquitetura vernacular de terra como contrapartida aos projetos de habitação social propostos no Brasil na atualidade.

\section{FUNDAMENTAÇÃO TEÓRICA}

O termo sustentabilidade passou a ser usado com mais frequência a partir da divulgação do Relatório Brundtland, publicado em 1987, que estabeleceu o conceito de sustentabilidade como sendo "o atendimento das necessidades do presente sem comprometer a possibilidade de as gerações futuras atenderem suas próprias necessidades" (WCED, 1981). 
Tal relatório demonstra a necessidade de intervenção no modelo de desenvolvimento econômico que se baseia na exploração desenfreada dos recursos naturais, e segundo ele essa intervenção deve ser feita na dimensão econômica, ambiental e social (WCED,1987).

De acordo com um artigo elaborado por Soraia Santos e Silvia Costa os autores Guy e Farmer (2001) elencam seis vertentes conceituais referentes a sustentabilidade aplicada a arquitetura, dentre essas elas estabelecem que a lógica Eco-cultural é uma análise sensorial do espaço em seu contexto regional e cultural sendo assim fonte do conhecimento ambiental, o fruto disso é uma arquitetura que se manifesta no espaço comum por meio de tecnologias construtivas vernaculares.

Quanto ao conceito de arquitetura vernacular Paul Oliver afirma que "ao usar o termo arquitetura vernácula abraço todos os tipos de construções feitas por pessoas de sociedades tribais, folclóricas, camponesas e populares onde um arquiteto ou designer não está envolvido no processo", ele afirma também que esse estilo arquitetônico está atrelado ao uso de materiais locais disponíveis levando em consideração características biogeoclimáticas regionais, por conta disso na opinião do autor "A arquitetura vernacular é a linguagem arquitetônica do povo que possui dialetos étnicos locais e regionais e, por esse motivo, pode ser compreendida como uma identidade cultural local."

A arquitetura popular é frequentemente rotulada como "construção" e não como "arquitetura" e no meio acadêmico estudos que abordam o tema são escassos mas quando abordados são vinculados à preservação, conservação e restauração do patrimônio edificado ou à problemática do déficit habitacional urbano (SANT' ANNA, 2013). Uma das razões dessa carência é o desprezo histórico da academia pelo tema (WEIMER,2005, p. XXXVII), portanto, dirigir o olhar para o universo popular implica questionar a noção hegemônica de arquitetura como arte e saber eruditos (JACQUES, 2003, p. 11-20) fato que auxilia diretamente na democratização da arquitetura.

A falta de disseminação de informações e a baixa valorização técnica dessa tipologia arquitetônica faz com que seja cercada de vários preconceitos relacionados à segurança e a durabilidade, a disseminação equivocada de que técnicas construtivas vernaculares de terra crua, por si só e não devido a problemas de execução, propagam doenças como o mal de chagas influenciam diretamente na marginalização dessa arquitetura, descartando assim possibilidades acessíveis 
de construção e promovendo o risco de desaparecimento dessas técnicas tradicionais, caso não haja intervenção na desvalorização em massa de tal técnica. (SANT' ANNA, 2013).

A autoconstrução com terra ainda é comum em zonas periféricas onde os recursos mais industrializados são de difícil acesso a população mais humilde por isso o uso de recursos locais é alternativa mais viável. A desvalorização dessa técnica está também relacionada a associação com a pobreza o que faz com que mesmo dentro de comunidades mais humildes os recursos naturais sejam rejeitados como antiquados e substituídos por versões de menor qualidade dos materiais de construção manufaturados (DA PONTE, 2012). Sendo assim é essencial a elaboração de trabalhos que valorizam técnicas vernaculares no âmbito acadêmico e técnico para a desconstrução de preconceitos.

\section{MÉTODO}

- Fazer uma análise bibliográfica sobre a história da arquitetura vernacular brasileira.

- Fazer uma análise bibliográfica sobre a representatividade cultural da arquitetura de terra.

- Comparar obras feitas com arquitetura vernacular e obras feitas com técnicas formais, analisar e catalogar o conforto térmico que cada uma proporciona.

- Entrevistar moradores residentes em construções vernaculares e tradicionais e comparar seus relatos.

- Analisar construções e criar uma tabela com cada elemento e etapa construtiva para realizar o orçamento de cada método construtivo para comparalos.

- Analisar moradas já construídas e documentar a quantidade de manutenções já realizadas nas diferentes tipologias arquitetônicas.

- Analisar a durabilidade das construções de acordo com registros bibliográficos e análise das construções já realizadas.

- Analisar se os métodos vernaculares são compatíveis ao código de obras do DF.

- Criar tabela com dados comparativos de cada material.

- $\quad$ Concluir com opções adaptativas dos programas de assistência a moradia caso as técnicas vernaculares sejam mais vantajosas. 


\section{A habitação de interesse social}

\subsection{Introdução}

A habitação é um instrumento que desempenha equilíbrio social, sendo esse um dos mais importantes direitos do homem além de ser uma condição básica para a promoção de sua dignidade, tornando-se um fator de estabilidade social e política (FLORIM e QUELHAS, 2004).

Szücs (2007) afirma que a habitação é um elemento de suma importância que permite cada indivíduo a possibilidade de referência de propriedade, de espaço e de proteção, por isso a moradia deve atender as todas as necessidades e anseios do morador, incluindo aspectos como a qualidade construtiva e a sustentabilidade ambiental

Um grande problema dos países em desenvolvimento é a falta de moradias dignas em virtude dos altos preços dos materiais de construção (LIMA, 2003), no brasil déficit habitacional chega a 7,9 bilhões de domicílios segundo o IPEA (Instituto de Pesquisa Aplicada). Surge assim a necessidade de se utilizar materiais alternativos que sejam ecológicos, de baixo custo e com disponibilidade local, de modo a baratear os custos das habitações (ANJOS, 2003).

\subsection{Contextualização}

O olhar da comunidade intelectual brasileira só passou a se atentar a questão da moradia social como um dever inerente ao arquiteto a partir da organização de um seminário pela IAB em 1963, momento no qual muitas revistas como a Arquitetura, revista carioca, e a Acrópole e Habitat, revista paulista, passaram a dar mais espaço para artigos a respeito do déficit habitacional e das péssimas condições de vida das parcelas mais carentes da população brasileira (BORTOLUCl, 2016).

Estéticas como o Brutalismo vieram na camada intelectual da arquitetura brasileira como tentativas de responder algumas questões que envolvem o déficit habitacional, com a intenção de mudar a maneira que os arquitetos atuam em habitações singulares para uma maneira que influenciaria a constituição de novos futuros para a coletividade arquitetônica. Apesar dessa estética ter nascido com uma forte intenção social sua aplicabilidade na periferia não foi tão intensa como no âmbito burguês, apesar da criação de alguns complexos habitacionais voltados para a arquitetura social.

Isso demostra uma falta de conexão entre os arquitetos e as massas, expressado pelo arquiteto Vilanova Artigas no seguinte trecho: "Mas é claro também que, enquanto a ligação entre os arquitetos e as massas populares não se estabelecer, não se organizar, enquanto a obra dos arquitetos não tiver a suma glória de ser discutida nas fábricas e nas fazendas, não haverá 
arquitetura popular. Até lá, uma atitude crítica frente à realidade." (CITAÇÃO ARTIGAS,1981, p.77.)

Apesar do fato de a visão brutalista estar voltada pra a problemática do uno e do múltiplo, a imaginação acerca do "povo" que circula no campo da época não é informada por uma experiência real de contato com essas populações e seus ambientes de vida. O maior déficit da visão da parcela intelectualizada dessa época era a interpretação do "povo" como uma categoria mítica, porém futura, ou como passivos espectadores do drama social nacional (BORTOLUCI, 2016).

No fim da década de 1960, começam-se a criar os primeiros canais que conectam diretamente 0 campo arquitetônico às experiências vividas dessas populações - entre eles, a publicação da importante pesquisa sobre habitação popular autoconstruída de Carlos Lemos e Maria Ruth do Amaral Sampaio. Essa nova visão passa a se associar a uma nova ideologia da arquitetura, focada na experimentação e valorização de materiais e técnicas tradicionais, no caráter político do processo de construção e na participação e autogestão como paradigmas para a elaboração do projeto arquitetônico e gerenciamento da construção para habitação social.

\subsection{Habitação de interesse social no Brasil}

Entre década de 1930 e 1964, o Estado brasileiro entrou de fato na produção de habitação social. $\mathrm{Na}$ Era Vargas, em meio ao desenvolvimentismo e à criação das leis trabalhistas, o poder público passou a investir diretamente na habitação social, como uma das frentes da promoção de um Estado de bem-estar. Nesse período, surgiram conjuntos habitacionais de proporções até então inéditas no Brasil, que incorporavam soluções da arquitetura moderna, inspiradas em arquitetos como Le Corbusier (1887-1965).

É o caso do Conjunto Residencial Prefeito Mendes de Moraes conhecido como Pedregulho -, localizado no Rio de Janeiro e concluído em 1951; e do Conjunto Habitacional IAPI Lagoinha, em Belo Horizonte, concluído em 1950. Esses edifícios eram financiados por instituições públicas, como os IAPs (Institutos de Aposentadoria e Pensões) associados às diferentes categorias profissionais, como industriários, bancários e comerciários, Departamentos de Habitação Popular de diferentes estados, e a Fundação da Casa Popular, órgão instituído em 1946 que foi o primeiro de âmbito nacional criado com o objetivo de prover moradia para a população de baixa renda (Fonte: Nexo Jornal).

Os IAPs, entretanto, desenvolveram uma política social incompleta ao assistir somente aos trabalhadores associados e empregados formalmente, deixando trabalhadores rurais, informais urbanos e a população de baixa renda fora desse processo (ALMEIDA, 2009) 
No início da década de 1960, quando ocorria uma migração ainda mais intensa da zona rural para as cidades, o país enfrentava uma crise habitacional. A produção promovida por órgãos como a Fundação da Casa Popular era insuficiente para solucionar o déficit habitacional das cidades brasileiras.

Em 1964, já durante a ditadura militar, foi criado o $\mathrm{BNH}$ (Banco Nacional de Habitação), um órgão federal de financiamento habitacional alimentado, a partir de 1967, principalmente pelo FGTS (Fundo de Garantia do Tempo de Serviço).

O banco arrecadava recursos que eram então transferidos para agentes privados responsáveis pela produção, distribuição e controle das habitações. Um dos primeiros representantes desse período foi o Conjunto Habitacional Cecap Guarulhos, projetado em 1967 (Fonte: Nexo Jornal).

$A$ atuação do $\mathrm{BNH}$ não favoreceu o benefício justo aos trabalhadores. Em um sistema que funcionaria como fundo de poupança que daria retorno em forma de habitação, somente $18 \%$ dos recursos foram aplicados às famílias que ganhavam menos de cinco salários mínimos. Desta maneira, após a construção em massa de 4 milhões de unidades, a classe média e as empreiteiras eram os reais beneficiados. A maioria dos trabalhadores, que representavam três quartos da população, continuou provendo moradia própria irregularmente e invadindo loteamentos públicos (ARANTES, 2011).

Entre as razões que levaram ao fim do BNH em 1986 estão inadimplência, corrupção e a crise econômica do período. Durante suas décadas de atuação, o banco produziu moradias de baixa renda em uma escala muito aquém de solucionar o déficit habitacional.

Na década de 1980, mobilizações sociais consolidadas em torno das associações de bairro passaram a reivindicar melhorias de infraestrutura urbana. Em conjunto com o poder público, essas associações atuaram, por meio de mutirões, na construção de conjuntos habitacionais.

Nesse modelo, autogestionado, abriu-se uma possibilidade de produção de habitação social para além da política macro do BNH. Os futuros moradores faziam a gestão do empreendimento e forneciam a mão de obra para a construção, contando com assessoria técnica de arquitetos, engenheiros e mestres de obras. Foram erguidos dessa forma o Conjunto Habitacional Rio das Pedras - Vila Mara, cuja construção teve início em 1989, e o Mutirão Paulo Freire, ambos na zona leste de São Paulo (Fonte: Nexo Jornal).

O caráter de direito básico da habitação só foi garantido em 2001 quando a função social do solo urbano foi ratificada através do Estatuto das Cidades (ROTTA, 2009). A partir deste houve um aumento das opções financeiras pela Caixa Econômica, definido em função da renda familiar do candidato. Como alternativa foi criado o PAR (Programa de Arrendamento Residencial) que tinha como objetivo exclusivo de atender às necessidades de moradia das populações que ganham entre três e seis salários mínimos 
nas cidades com mais de 100.000 habitantes. Este representou grande avanço, superando algumas críticas que se direcionavam aos modelos desenvolvidos pelo antigo BNH (DAMÉ, 2008).

Foi criado em 2009 o Programa Minha Casa Minha Vida que deu início a uma nova fase da história da produção de habitação social no país. Criado no segundo mandato do presidente Luiz Inácio Lula da Silva, o programa atende a diferentes faixas de renda e, em sua origem, era financiado com recursos do orçamento do Ministério das Cidades, repassados para a Caixa Econômica Federal.

Dez anos após seu lançamento, o programa Minha Casa Minha Vida registra recordes históricos no número de unidades entregues $(4,4$ milhões, que beneficiaram em torno de 20 milhões de pessoas), mas é criticado por tê-las construído em grande parte em lugares afastados, desprovidos de infraestrutura (Fonte: Nexo Jornal).

As especificações mínimas para construção de unidades habitacionais são realizadas de acordo com cada região brasileira onde será instalada a obra. (MINISTÉRIO DAS CIDADES, 2009)

Todas as ações governamentais de produção de habitação social geraram um avanço no déficit habitacional, mas nenhuma chegou perto de solucionar o problema. Além de os números de habitações construídas estarem distantes do número referente a falta de moradia; tais construções não atenderam as expectativa dos moradores, como é exemplificado por pedregulhos, gerando o abandono das obras; favoreceram na criação de periferias, o que impede a integração dos usuários com os centros mais industrializados; demonstraram a falta de prioridade quanto ao engajamento social, cultural e ambiental.

\subsection{Habitação de Interesse social no Distrito Federal}

A habitação de interesse social no Distrito Federal remonta desde a época da fundação da Capital Federal, com a criação da Sociedade de Habitações Econômicas de Brasília - SHEB (1962), posteriormente a Sociedade de Habitação de Interesse Social - SHIS (1964), o Instituto de Desenvolvimento Habitacional do Distrito Federal - IDHAB (1994) e atualmente a Companhia de Desenvolvimento Habitacional - CODHAB (2007).

Governos anteriores priorizaram a distribuição de lotes mal urbanizados, sem, entretanto, primar por uma rigorosa seleção dos contemplados ou mesmo assegurar que os atendidos tivessem condições de consolidar no lote um atendimento habitacional completo. Os ciclos de distribuição de lotes como solução de moradia produziram diversas distorções desde a sua origem, quando a distribuição era promovida pelos 
órgãos ligados ao serviço social sem a participação dos órgãos que lidavam com a questão habitacional.

Se por um lado à farta distribuição de terra comprometeu o desenvolvimento urbano do Distrito Federal, por outro, é fácil perceber que não foi o suficiente para diminuir o déficit, o que pôde ser facilmente constatado por dados oficiais que apontam o DF como a Unidade da Federação onde o maior número de pessoas, em termos percentuais, não é proprietária do lugar onde vive.

Efetivamente, até junho de 2006 o Governo do Distrito Federal não possuía uma legislação consolidada que fornecesse diretrizes à Política Habitacional.

Em 26 de junho de 2006, foi aprovada pela Câmara Legislativa do Distrito Federal a Lei Distrital $n^{\circ}$. 3.877 que dá as diretrizes da Política Habitacional, tanto aquela de interesse social quanto a de mercado. Embora represente algum avanço, a lei deixa vácuos em questões como a regularização fundiária e a qualificação de moradias uma vez que a cultura local não entende estes aspectos como problemas habitacionais (Plano Distrital de Habitação de Interesse Social, GDF,2012).

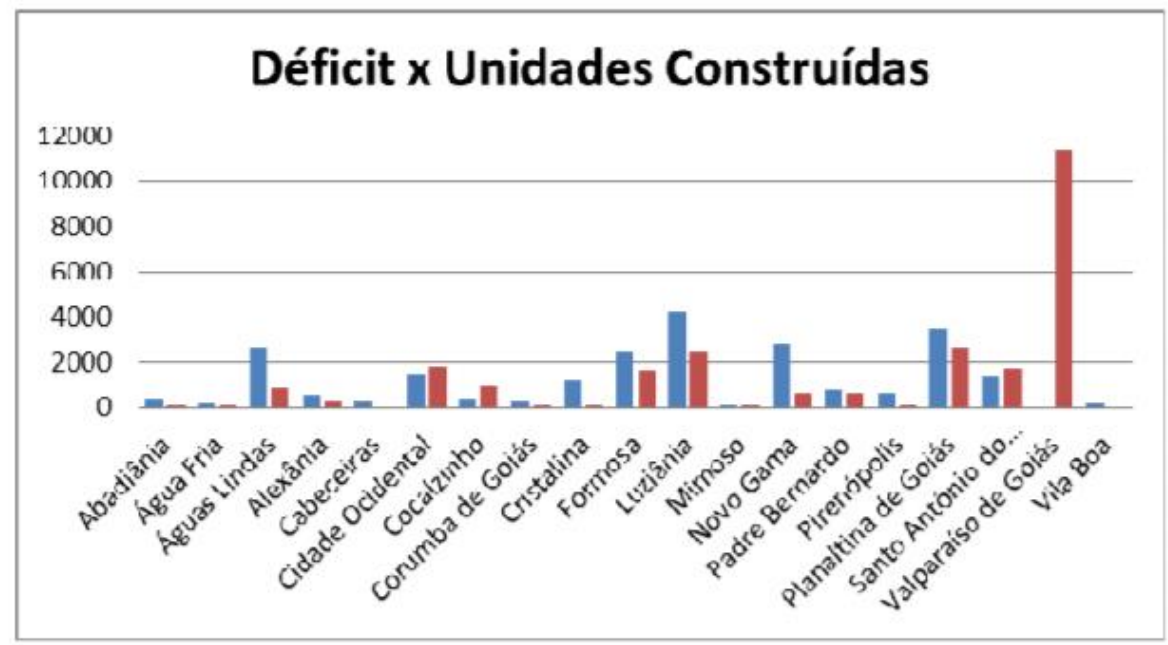

Legenda

Déficit Habitacional Unidades construídas pelo MCMV

Gráfico 1- A relação entre o déficit habitacional e moradias construídas pelo programa Minha Casa Minha Vida (Fonte:http://www.seduh.df.gov.br/wpconteudo/uploads/2017/10/diagnostico_preliminar_plandhis.pdf)

O gráfico acima demonstra como o programa Minha Casa Minha Vida distribui as habitações levando em consideração apenas os recursos econômicos gerando assim a periferias extensas. Fica evidente na imagem que a maior parte das construções realizadas não se encontram associadas aos locais de demanda, fato que gera dissociação da população mais humilde dos centros urbanos nos quais se 
encontram as oportunidades de emprego e educação fomentando assim um ciclo de desqualificação de seus usuários.

\section{Sobre arquitetura popular com terra crua}

\subsection{Introdução}

Ao analisar moradias autoconstruídas foi observado que a maneira que os arquitetos projetavam casas de interesse social não satisfazia as vontades e necessidades populares por exemplo, a prática comum de construir mais de uma moradia no mesmo lote, a fim de propiciar renda extra aos proprietários por meio do aluguel da residência suplementar, que em muitos casos compartilhava banheiros, e tanques de lavagem de roupas com a casa da família proprietária. Notaram também a primazia da cozinha e de outros espaços de convivência na habitação autoconstruída, tanto em termos construtivos (pelo espaço considerável ocupado no lote) quanto na sociabilidade das famílias - em detrimento da valorização "burguesa" do conforto à hora de dormir e do lazer individual, o que, em termos projetuais, dava prioridade aos dormitórios na prática dos arquitetos que serviam às classes médias. (BORTOLUCI, 2016).

Como Rapoport (1969) e Oliver (2006), Guidoni (1980) também destaca a casa como a tipologia arquitetônica que mais preserva as tradições populares e atua como um indicador privilegiado das relações comunitárias por meio do seu aspecto exterior e de sua adaptabilidade ao espaço disponível. Observa que o interior da casa popular é pouco estudado em termos de cultura do espaço habitado, dos modelos de seleção e agregação de objetos e da relação com a estrutura edilícia. Observa que nessas casas os ambientes mais importantes (área de dormir, de rezar e a cozinha) são rigorosamente estruturadas espacialmente e que os objetos e instrumentos de trabalho sempre prevalecem sobre a mobília, a qual é tratada como entidade isolada e relativamente independente do ambiente arquitetônico (GUIDONI, 1980, p. 206-216).

O estudo sobre as habitações autoconstruídas mostra também como a população usa de saberes herdados para suprir necessidades atuais, de forma que ao olhar para obras da arquitetura popular brasileira é possível aprendermos técnicas de construção sustentáveis que representam um alto grau de engajamento cultural o que influencia diretamente na qualidade de vida do morador.

Braun (2001) define construções sustentáveis como, complementa que a adaptação das construções à paisagem circundante é uma arte em si só, pois implica descobrir os movimentos favoráveis da natureza a fim de seguir sempre o caminho da menor resistência, ou seja, do menor gasto de energia.

Quanto a sustentabilidade no Brasil, a meta da sustentabilidade aplicada à arquitetura, é em grande parte definida em termos de adequação climática, surgem projetos arquitetônicos e experiências no campo da construção que utilizam técnicas construtivas tradicionais, como o adobe 
e o pau a pique, e em trabalhos experimentais de arquitetos, engenheiros e outros profissionais das áreas tecnológicas, que buscam 0 aperfeiçoamento dessas técnicas como base para o desenvolvimento de sistemas construtivos mais baratos, como o solo-cimento. Com relação à arquitetura popular, ou aquela produzida fora dos circuitos formais e especializados, o tema da sustentabilidade não é muito explorado, embora seja amplamente reconhecida a sua adequação climática

Soares (IPEC, 2008) afirma que é possível habitar este planeta de maneira mais saudável, vivendo bem, sem destruir o meio ambiente, sem consumir à exaustão e sem poluir. Também é possível substituir nas construções, grande parte do cimento, dos plásticos e dos materiais tóxicos por elementos inócuos existentes na natureza, além do uso de materiais em seu estado natural, disponíveis na região. Soares (IPEC, 2008), acrescenta que este tipo de construção utiliza materiais ecológicos e reduz o impacto ambiental através de técnicas da arquitetura vernacular, algumas delas com centenas de anos de história e experiência, tendo como característica a preferência por materiais do local, como a terra, reduzindo gastos com fabricação e transporte e construindo habitações com custo reduzido e que oferecem excelente conforto térmico.

Quando se trata da climatização das construções, um fator importante é o isolamento térmico, pois evita desperdícios e aumenta o rendimento térmico da energia empregada. $O$ isolamento térmico depende de dois pontos: na soma dos fechamentos de toda a superfície do exterior do edifício e no coeficiente de transmissão de calor dos materiais que compõem esta envolvente. Isto é, quanto menor for a superfície externa das habitações, menor será a troca de calor (Adam, 2001).

A indústria da construção civil é responsável pelo maior consumo dos recursos naturais no planeta e ainda causam prejuízos à saúde humana, pois muitos materiais possuem composições químicas agressivas à saúde (BioConstruindo, 2006)

Até hoje esse tema é discutido entre lideranças populares de movimentos de moradia e entre arquitetos e cientistas sociais que tratam da questão. Isso fica claro nas discussões recentes acerca do Programa Minha Casa Minha Vida. O programa é fundamentalmente orientado pela ideia de que o problema da habitação é quantitativo (o "déficit habitacional") e deve ser resolvido a partir de uma articulação entre mercado imobiliário e Estado. O programa relega a autogestão e a participação efetiva de movimentos de moradia na produção da habitação popular a uma modalidade com poucos recursos, o Minha Casa Minha Vida - Entidades, além de desconsiderar quase por completo outras dimensões do direito à cidade para além do acesso à moradia própria - em geral, esta também de baixa qualidade (BORTOLUCI, 2016). 


\begin{tabular}{|lccc|}
\hline Material & Densidade & $\begin{array}{l}\text { Emissões } \\
\text { por Kg }\end{array}$ & $\begin{array}{l}\text { Emissões } \\
\text { por m }\end{array}$ \\
\hline & $\mathrm{Kg} / \mathrm{m}^{3}$ & $\mathrm{Kg} \mathrm{CO} / \mathrm{Kg}$ & $\mathrm{Kg} \mathrm{CO} / \mathrm{m}^{\mathbf{3}}$ \\
\hline Taipa (sem estabilização) & 2200 & 0,004 & 9,7 \\
\hline Adobe & 1200 & 0,06 & 74 \\
\hline Concreto preparado in loco & 2360 & 0,14 & 320 \\
\hline Concreto pré-fabricado, 2\% de aço & 2500 & 0,18 & 455 \\
\hline Parede de ladrilho maciço & 1600 & 0,19 & 301 \\
\hline Parede de ladrilho oco & 670 & 0,14 & 95 \\
\hline
\end{tabular}

Tabela 1 - Comparação das emissões de dióxido de carbono (CO2) na produção de

paredes de diversos materiais construtivos.

(Fonte: BESTRATEN , 2011; Tradução, MARQUES, 2018)

A Tabela 1 demostra como as técnicas de arquitetônicas de terra crua emitem menos poluentes na atmosfera quando comparadas a técnicas industrializadas.

\subsection{Adobe}

\subsubsection{Conceito}

$\mathrm{O}$ arquiteto e historiador mineiro Sylvio de Vasconcellos, no livro Arquitetura no Brasil: sistemas construtivos define o adobe como: Os "adôbos" são tijolos de barro, que são compactados manualmente em formas de madeira e postos a secar na sombra e depois ao sol, devendo o barro conter uma quantidade de areia, fibras vegetais ou estrume de boi para que se tenha consistência. $O$ assentamento e o reboco são feitos de barro, podendo receber reboco de cal e areia.

Patrick Bardou autor do livro Arquitecturas de Adobe define como: A fabricação de tijolos através da utilização de solo, selecionado pelos antigos construtores por sua composição arenosa, que são moldados em fôrmas de madeira secos diretamente ao sol ou a sombra por algumas semanas.

O conforto térmico oferecido pelo adobe é altamente reconhecido por diversas fontes:

O desempenho térmico dos edifícios com paredes de cob é, no entanto, lendário (...) O chalé de cob em Devon tinha a reputação de ser aconchegante no inverno e fresco no verão. (HEATHCOTE, 2010)

Uma casa construída em terra apresenta bom comportamento térmico e acústico devido à grande inércia térmica das suas paredes, que se comportam como uma barreira eficaz contra as intempéries. (CANCELA, 2013) 
Habitações construídas com terra podem armazenar calor por ser um material denso, com resistência térmica relevante. Em regiões onde a amplitude térmica é alta, a terra pode balancear a temperatura dos ambientes interiores por vias passivas, diminuindo a quantidade de energia necessária à climatização artificial. (MAIA, 2014)

Em uma pesquisa realizada em Nova Deli, Índia, informaram que a construção de casa de barro tem efeito de ar condicionado natural, porque os quartos são frescos durante o dia e quentes durante a noite. (CHEL e TIWARI, 2009)

"Ela tem um excelente conforto acústico, é muito fresca durante o dia e agradável à noite. Uma vez medi a temperatura externa e a interna, num pico de sol, e a diferença era de 6 graus a mais do lado de fora" (Citação: Antônio Zayek; Fonte: https://casa.abril.com.br/casasapartamentos/adobe-materia-prima-tao-antiga-pode-ser-alternativapara-o-futuro/)

Carignani e Reis (2014), colocam que as paredes em tijolo de adobe apresentam conforto térmico que se adapta ao clima local. Em relação ao conforto higrotérmico, pelo fato de não queimar o barro, o tijolo de adobe possui uma capacidade de absorver e perder a umidade de maneira mais rápida que os demais materiais de construção.

\subsubsection{Engajamento Social}

Sobre a sustentabilidade social Maia (2014) afirma que a percepção está também relacionada ao senso de temporalidade, onde os materiais naturais "contam sua origem e seu uso histórico pelo homem, além de expressar história e idade."

A habitação construída com terra pode proporcionar mais do que a neutralidade exigida pelas normas: proporciona aos moradores prazer, bem-estar, expressão de seu corpo e cultura, além da expansão de suas emoções e sentimentos, evocando sentidos e sentimentos humanos e emocionando. (MAIA, 2014)

[...] uma habitação de terra torna-se confortável e aconchegante ao proporcionar ao usuário a sensação de construção feita por mãos humanas, quase como um artesanato. (MAIA, 2014)

\subsubsection{Comportamento térmico do material}

Para determinar o comportamento térmico do material é necessário analisar cálculos, simulações e medições em loco, além de comparar tais com as normas vigentes que regulam a adequação dos sistemas construtivos a realidade.

São as propriedades dos elementos construtivos que irão

definir o comportamento da envolvente com relação ao ambiente 
externo, que está principalmente relacionado as trocas de calor com o meio. Na envoltória de uma edificação a transmissão do calor irá ocorrer quando existir uma diferença entre as temperaturas da superfície externa e interna, sendo que o fluxo de calor irá sempre da superfície mais quente para a mais fria. (FROTA e SCHIFFER, 2001)

É importante ressaltar que de acordo com as características arquitetônicas, como tamanho de esquadria, tamanho da superfície de contato com os raios solares esses valores podem sofrer variações. Como também de acordo com a nebulosidade do dia que altera diretamente na incidência de raios solares.

A condutividade térmica é um fator determinante para o conforto térmico do ambiente. Essa propriedade é definida pela ABNT de 2005 como propriedade física de um material homogêneo e isótropo, no qual se verifica um fluxo de calor constante, com densidade de $1 \mathrm{~W} / \mathrm{m}^{2}$, quando submetido a um gradiente de temperatura uniforme de 1 Kelvin [ou grau célsius] por metro. Quando existe transferência de calor por condução, convecção e radiação em materiais porosos recomenda-se usar o termo 'condutividade térmica aparente'.

Essa propriedade física depende de três fatores, sendo esses a densidade, quanto maior a densidade do material, maior sua condutividade, a natureza química, os materiais amorfos, como os cerâmicos, polímeros e metais, são geralmente menos condutores que os cristalinos, a umidade, como a água é mais condutora que o ar, um material que absorve água terá sua condutividade alterada pelo seu teor de umidade.

No que concerne ao comportamento térmico de uma construção, para casos de climas em que o isolamento é necessário, como o clima temperado de Portugal, a eficiência do material empregado será tanto maior quanto menor for seu coeficiente de condutividade térmica, pois maior será sua resistência térmica e menor será seu coeficiente de transmissão térmica o que proporcionará uma menor perda de energia ou um maior isolamento das temperaturas externas (TORGAL, 2009).

Segundo Ferraz Junior, (1995) o ar possui valores de condutividade muito baixos, da ordem de $0,026 \mathrm{~W} / \mathrm{mK}$, portanto, solos mais compactados e solos cujos vazios intergranulares forem preenchidos por estabilizantes ou matérias muito finas terão maiores valores de coeficiente de condutividade térmica. Por conta disso tanto a granulometria da areia adicionada ao solo quanto a compactação desse afeta diretamente na qualidade térmica do tijolo.

É por isso que por ser uma técnica artesanal está sujeita a variações técnicas, por isso é extremamente importante que para a reprodução em massa e otimização dessa técnica ela seja acompanhada por um profissional. 


\begin{tabular}{|c|c|c|c|}
\hline Modelo & Fonte & $\begin{array}{l}\text { Condutividade } \\
\qquad(\mathrm{W} / \mathrm{mK})\end{array}$ & $\begin{array}{r}\text { Densidade } \\
\left(\mathrm{Kg} / \mathrm{m}^{3}\right)\end{array}$ \\
\hline Alvenaria de adobe & DIN V 4108-4:1998-10* & 1,20 & 2000 \\
\hline $\begin{array}{l}\text { Alvenaria de adobe com aditivos (solo } \\
\text { arenoso }+10 \% \text { de cimento }+4 \% \text { de silicato } \\
\text { de sódio) }\end{array}$ & FERREIRA, 2003 & 0,49 & 1868 \\
\hline Alvenaria de adobe & $\begin{array}{l}\text { Simões (2009, Apud FRANCISCO, } \\
\text { 2009) }\end{array}$ & 1,05 & 1800 \\
\hline Alvenaria de adobe & DIN V 4108-4:1998-10* & 0,95 & 1800 \\
\hline Alvenaria de adobe & BAHADORI e HAGHIGHAT, 1986 & 0,67 & 1700 \\
\hline Alvenaria de adobe & DIN V 4108-4:1998-10* & 0,80 & 1600 \\
\hline Alvenaria de adobe - Terra de Devon & $\begin{array}{l}\text { GOODHEW e GRIFFITHS (2000, apud } \\
\text { GOODHEW e GRIFFITHS, 2004) }\end{array}$ & 0,45 & 1450 \\
\hline Alvenaria de adobe & DIN V 4108-4:1998-10* & 0,60 & 1400 \\
\hline Terra para adobe com palha & $\mathrm{BINICI}, 2007$ & 0,21 & 1253 \\
\hline Alvenaria de adobe & DIN V 4108-4:1998-10* & 0,50 & 1200 \\
\hline Alvenaria de adobe & BAHADORI e HAGHIGHAT, 1986 & 0,25 & 1000 \\
\hline Bloco de terra leve & DIN V 4108-4:1998-10* & 0,40 & 1000 \\
\hline $\begin{array}{l}\text { Alvenaria de adobe com e fragmentos } \\
\text { mineiras }\end{array}$ & $\begin{array}{l}\text { OODHEW e GRIFFITHS (2000, apud } \\
\text { GOODHEW e GRIFFITHS, 2004) }\end{array}$ & 0,24 & 800 \\
\hline Bloco de terra leve & DIN V 4108-4:1998-10* & 0,30 & 800 \\
\hline Terra para adobe com palha & GOODHEW e GRIFFITHS, 2004 & 0,18 & 440 \\
\hline Bloco cerâmico & NBR 15220, 2005 & 0,90 & 1600 \\
\hline Bloco de concreto & NBR 15220, 2005 & 1,75 & 2400 \\
\hline
\end{tabular}

Tabela 2 - Comparação das emissões de dióxido de carbono (CO2) na produção de paredes de diversos materiais construtivos. (Fonte: MARQUES, 2018 com base nas fontes especificadas na tabela)

Segundo as constatações feitas pelas arquitetas Jhennyfer Loyane Gama Pires e Darja Kos Braga, em um estudo de caso em habitações de interesse social em Planaltina (Goiás), verificase que o tijolo de adobe - se comparado com o tijolo cerâmico furado - tem um desempenho levemente inferior em relação à transmitância térmica, porém sua capacidade térmica apresenta condições significativamente mais favoráveis. É importante levar em conta que as casa analisadas possuíam telha de fibrocimento o que influencia significam este no aumento da temperatura interna e na perda de conforto térmico.

BAHADORI e HAGHIGHAT, no artigo Thermal performance of adobe structures with domed roofs and moist internal surfaces, de 1986, avaliaram a temperatura média radiante em ambientes de adobe e tijolo cerâmico no verão do Irã, uma região quente e seca. Foi estudado principalmente 0 efeito de diferentes intensidades de ventilação e o efeito de se manter as paredes internas úmidas. Eles concluíram que, tomados devidos cuidados para manter boas taxas de ventilação, as temperaturas das superfícies internas podem ser reduzidas sensivelmente quando estas superfícies são mantidas úmidas, sendo que qualquer outro material cuja superfície pode ser mantida uniformemente úmida e resfriada pode produzir os mesmos resultados. 


\section{Compatibilidade com a norma}

A seguinte análise de Pires e Braga (2018) foi feita em relação a Norma de Desempenho NBR 15.575 que estabelece dois métodos para a avaliação do desempenho térmico das edificações e dentre eles o método simplificado. Este método se dá com base nos cálculos escritos na Norma NBR 15220-2 Desempenho térmico de Edificações Parte 2: Métodos de cálculo da transmitância térmica, da capacidade térmica, do atraso térmico e do fato solar e elementos e componentes de edificações.

Foram comparados os cálculos deste método para as casas construídas tanto com tijolo de adobe quanto com o tijolo cerâmico furado.

\begin{tabular}{|c|c|c|c|c|}
\hline Situações & $\begin{array}{c}\text { Transmitância } \\
\text { térmica }\left(\mathrm{m}^{2} \cdot \mathbf{K}\right) / \mathbf{W}\end{array}$ & $\begin{array}{c}\text { Atendimento a NBR } \\
15.575\end{array}$ & $\begin{array}{c}\text { Capacidade térmica } \\
\mathbf{k J}\left(\mathbf{m}^{2} . \mathbf{K}\right)\end{array}$ & $\begin{array}{c}\text { Atendimento a NBR } \\
15.575\end{array}$ \\
\hline Tijolo de adobe 01 (A1) & 2,99 & Não & 132,25 & Sim \\
\hline Tijolo cerâmico $01(\mathrm{C} 1)$ & 2,69 & Não & 98,3 & Não \\
\hline
\end{tabular}

Tabela 3- Resultados de transmitância e capacidade térmica dos cenários $A 1$ e C1.

(Fonte: PIRE E BRAGA,2018)

De acordo com a Norma de Desempenho, o valor de transmitância térmica para superfícies de cor escura - o caso das edificações em estudo - deve ser menor ou igual a 2,5 (m2.K) N. A capacidade térmica deve ser maior ou igual a $130 \mathrm{~kJ}(\mathrm{~m} 2 . \mathrm{K})$. Com base nesses dados é possível identificar que o tijolo de adobe possui uma transmitância térmica acima do estabelecido e uma capacidade térmica dentro do adequado. O tijolo cerâmico de 8 furos possui ambos os parâmetros avaliados fora do estabelecido como adequado.

Comparando os resultados encontrados e os desempenhos estabelecidos pela NBR 15575, é possível identificar que o sistema de cobertura de telha de fibrocimento possui grande interferência no desempenho térmico da envoltória devido a sua transmitância térmica ser muito alta, de 4,59(m2.K) $\mathrm{W}$.

$O$ estudo chegou às seguintes conclusões:

- As diferenças de temperatura encontradas, por meio do método de simulação computacional, para o sistema construtivo com tijolo de adobe são mais favoráveis e atingem o nível mínimo com intervenção no sistema de cobertura, inserindo forro rebaixado, e com alteração da absortância solar dos seus elementos nas superfícies externas. As simulações com o tijolo cerâmico furado mostraram que em nenhum cenário estabelecido, nem para o verão e nem para o inverno, atende ao desempenho mínimo para essa tipologia arquitetônica. $\mathrm{O}$ fato de rebocar o tijolo de adobe internamente e externamente com argamassa de barro, ou seja, aumentado a sua massa se chega a números próximos aos estabelecidos pela NBR 15575 de acordo com o cálculo simplificado.

As temperaturas externas causam apenas $18 \%$ de desconforto por calor em Brasília/DF, mas como comprovado também nas simulações do presente trabalho, internamente o desconforto por calor é maior que desconforto por frio. Entende-se que isso se caracteriza porque o desconforto por frio se dá, na maioria das vezes, nos períodos noturnos e grande parte das edificações preservam as temperaturas internas dentro da zona de conforto, como demostraram as análises para o dia típico de inverno. 
- $\quad$ Conclui-se que a utilização dos tijolos de barro cru, conhecidos desde a arquitetura vernacular como tijolo de adobe, demonstrou um melhor desempenho térmico que o bloco cerâmico furado, pois com as interferências propostas se alcançou o atendimento a norma, diferente do demonstrado nos cenários com tijolo cerâmico furado. Construções que utilizam técnicas de construção vernacular reduzem o impacto ambiental, os gastos com fabricação e transporte, construindo habitações com custo reduzido e, de acordo com os resultados obtidos neste trabalho, oferecem um melhor desempenho térmico que edificações construídas no método tradicional da região, sendo necessário intervenções mínimas para garantir o cumprimento à Norma de Desempenho.

\section{Aferição de dados em loco}

O clima do Distrito Federal e entorno é tropical de altitude com um verão úmido e chuvoso e um inverno seco e relativamente frio. A média das temperaturas mínimas mensais varia de $10 \circ \mathrm{C}$ no mês de julho até $180 \mathrm{C}$ no mês de dezembro. As médias das temperaturas máximas oscilam de $250 \mathrm{Cem}$ junho a $290 \mathrm{C}$ em setembro. De acordo com os dados disponibilizados na plataforma Projeteee, plataforma nacional que agrupa soluções para um projeto de edifício eficiente, as temperaturas externas causam $18 \%$ de desconforto por calor e $46 \%$ por frio, gráficos 01 e 02 . Porém, internamente o problema de calor é maior que de frio, isso porque o desconto por frio se dá mais nos períodos noturnos e a maioria das edificações preservam as temperaturas internas dentro da zona de conforto. (PIRES e BRAGA, 2018)

Gráfico de temperatura e zona de conforto

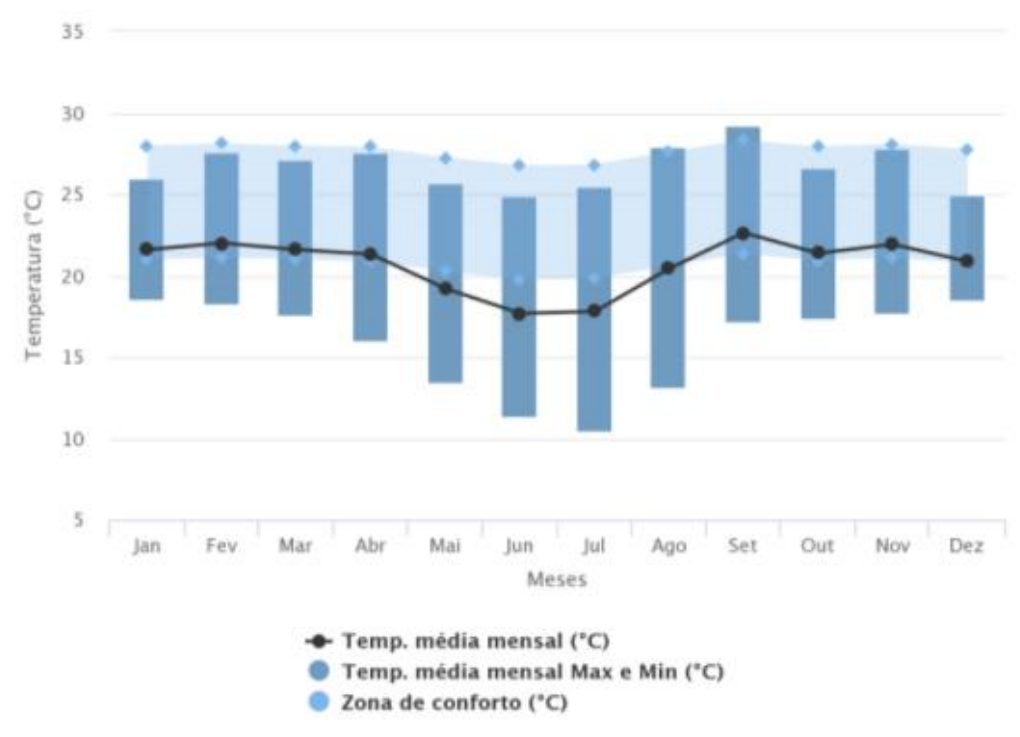

Gráfico 2- Temperatura e zona de conforto em todas as estações em Brasília/DF. (Fonte: Projeteee, 2020)

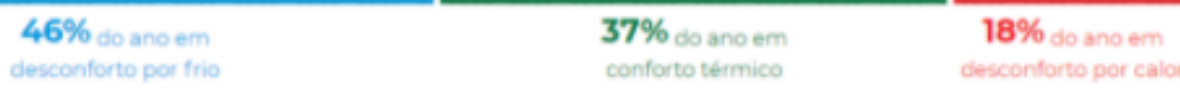


Gráfico 3- Condições de conforto em todas as estações em Brasília/DF. (Fonte: Projeteee, 2020)

Foi analisada uma arquitetura vernácula localizada em uma fazenda nos arredores de Brasília, próxima a Valparaiso. Essa foi construída em 1890 e corrobora com as observações feitas nos anos 1960 como mostrada nos texto acima, possui muitas casas no mesmo lote compartilhando a mesma área de lazer voltada para os fundos, possui as áreas de cozinha, sala e exercício religioso com as áreas mais avantajadas quando em comparação as áreas de lazer individual.

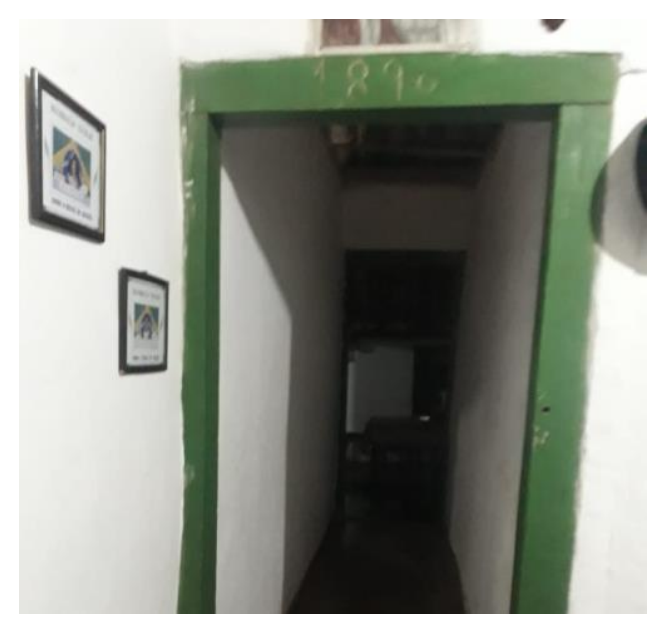

Figura 1- Batente da porta indicando o ano de construção. (Fonte: Própria)

Vale ressaltar que na data de medição o tempo se encontrava encoberto e havia chovido no dia anterior, de forma que a absorção de raios solares pelo material não estava em seu pico. Portanto a variação de temperatura interna e externa não estava nos valores mais altos possíveis. 


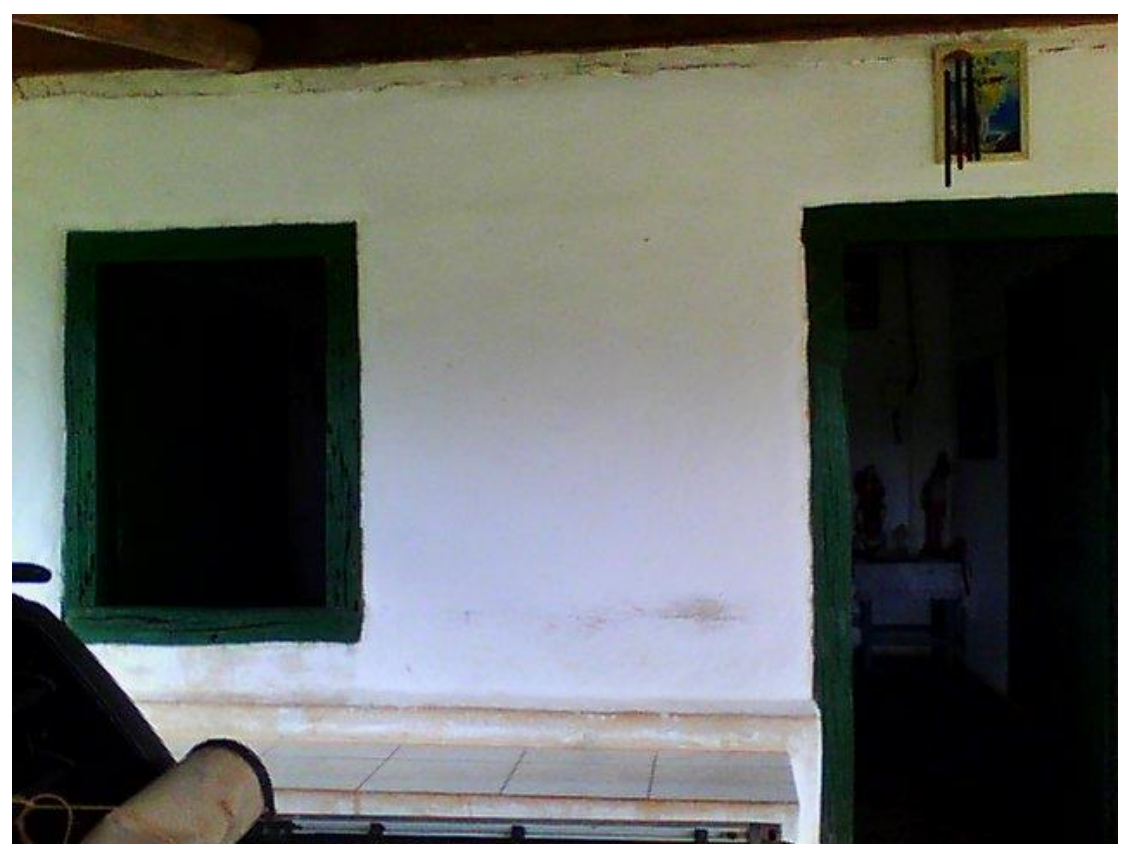

Figura 2- Fachada frontal encoberta por um beiral de mais de 5M. (Fonte: Própria)

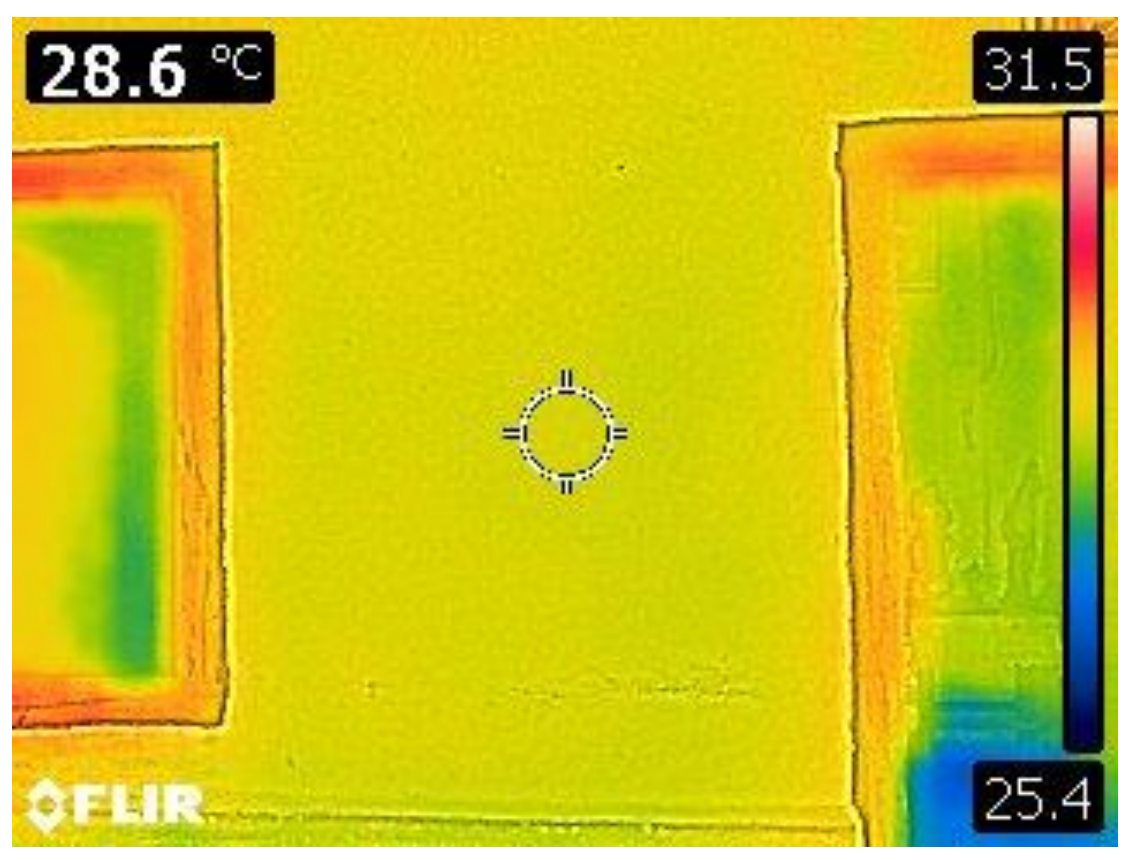

Figura 3- Fachada frontal encoberta por um beiral de mais de $5 \mathrm{M}$, foto termográfica. (Fonte: Própria) 


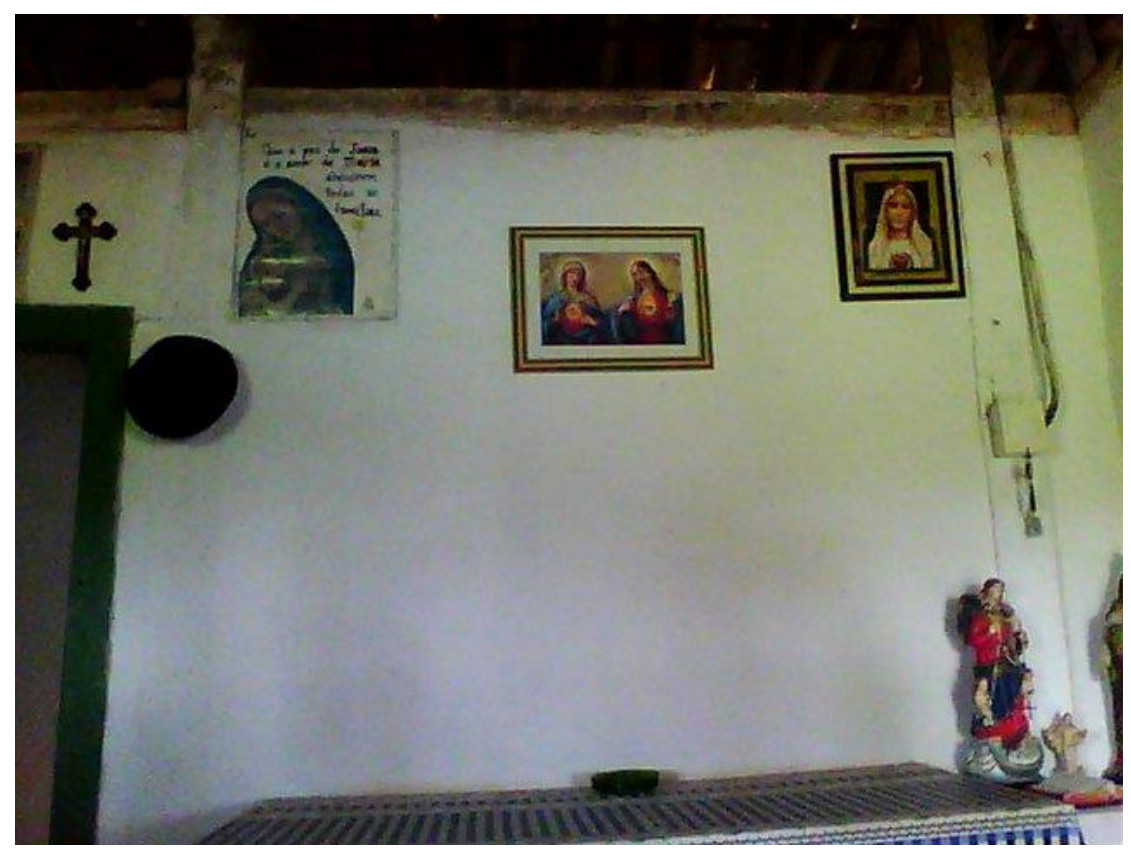

Figura 3- Parede interna em frente a fachada frontal. (Fonte: Própria)

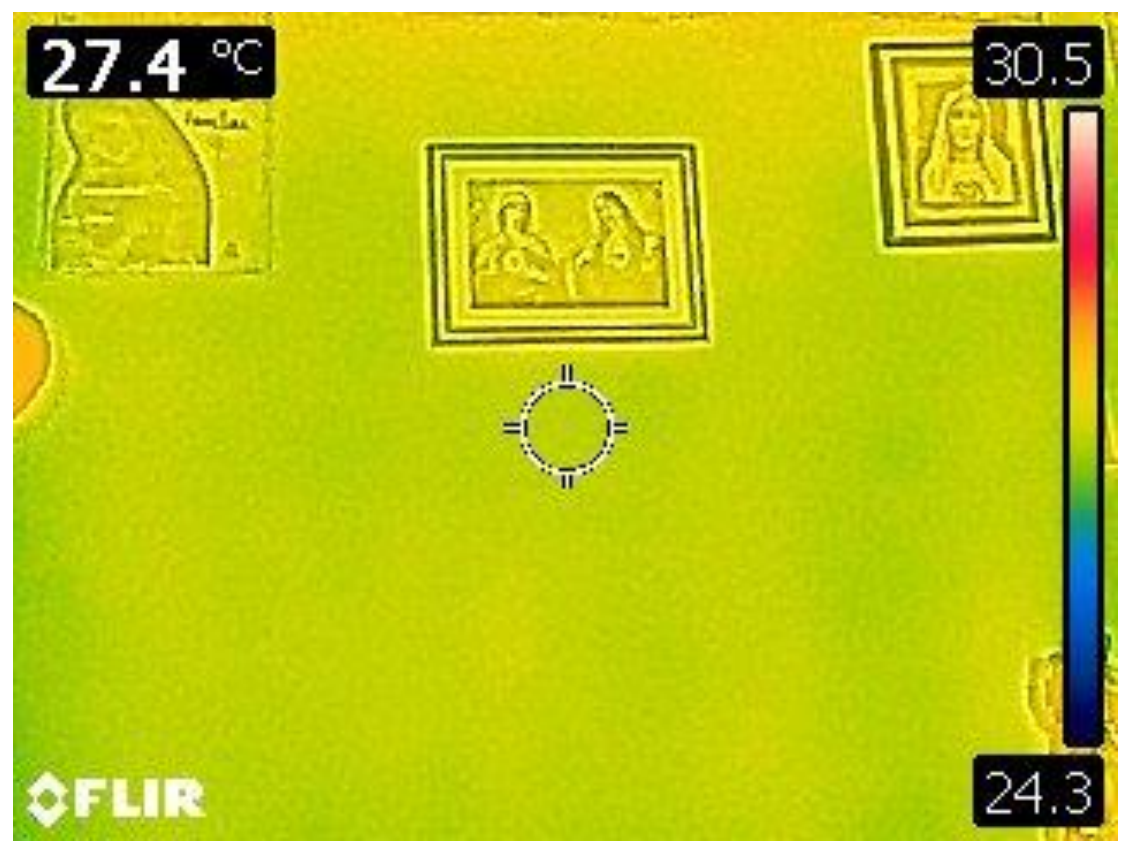

Figura 4- Parede interna em frente a fachada frontal, foto termográfica. (Fonte: Própria)

Fica claro o conforto térmico da parede de Pau-a-Pique sendo que em um mesmo cômodo a diferença térmica de superfícies chega $1.2 \mathrm{C}$, com a externa possuindo a maior temperatura relativa a $27.4 \mathrm{C}^{\circ}$ e a interna relativa a $28.6 \mathrm{C}^{\circ}$. 


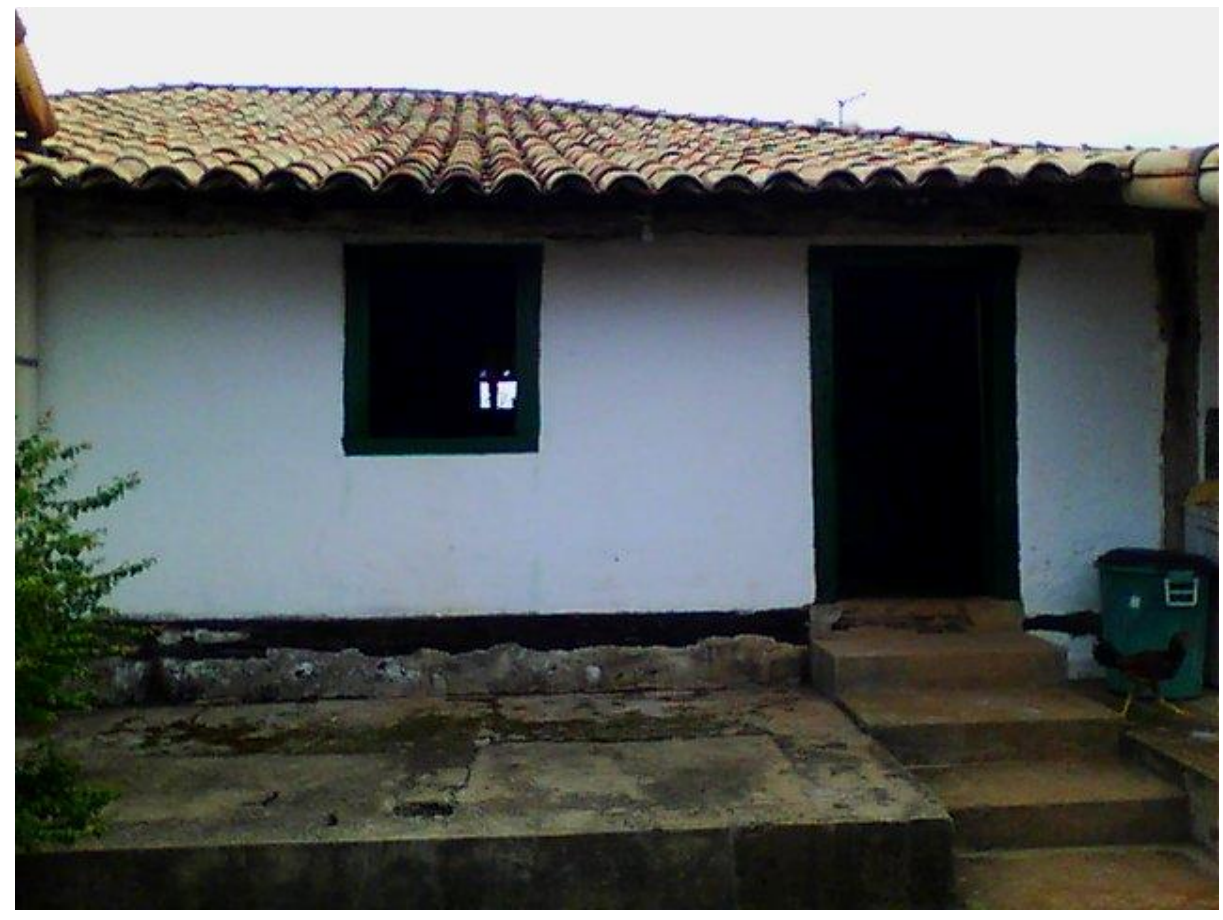

Figura 5- Parte externa da parede posterior. (Fonte: Própria)

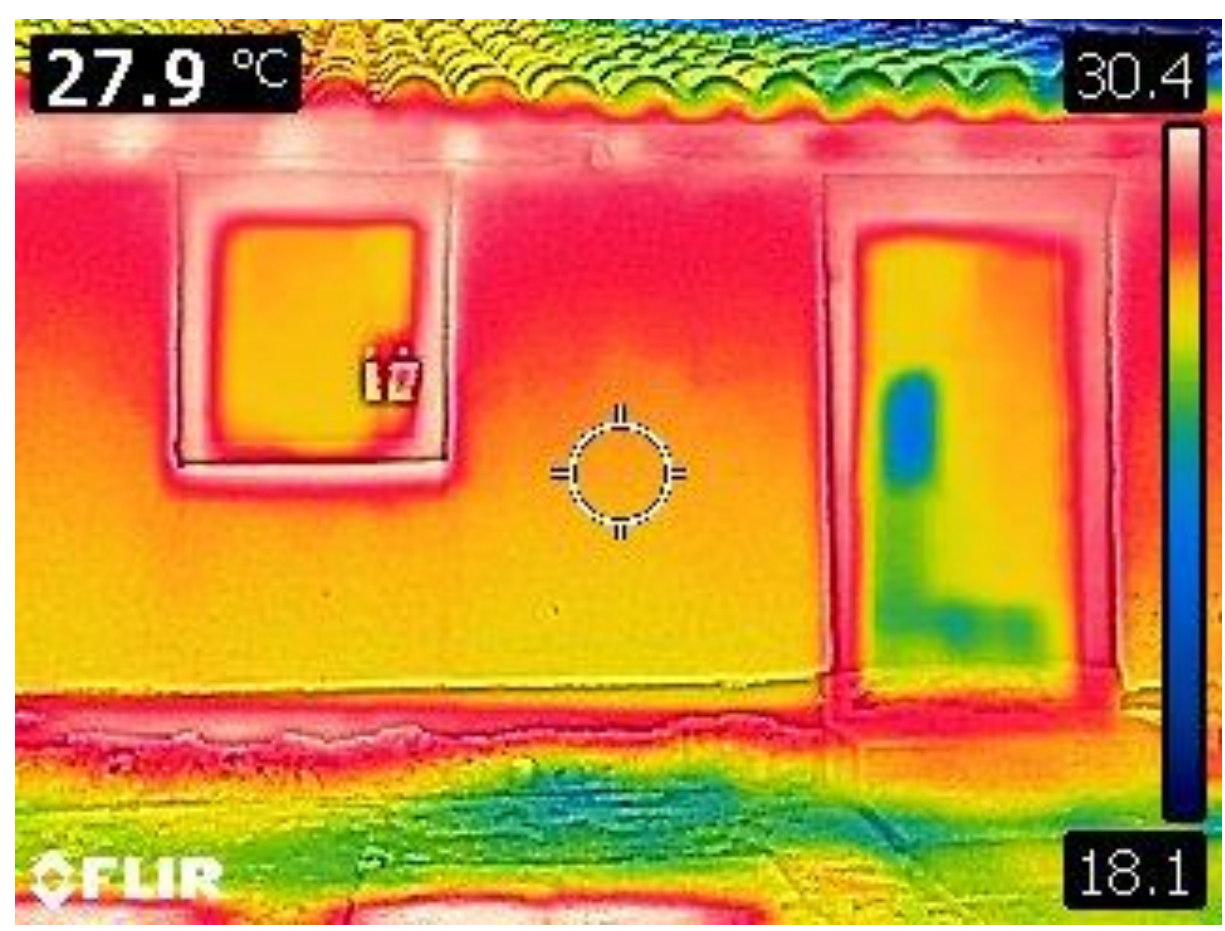

Figura 6- Parte externa da parede posterior, foto termográfica. (Fonte: Própria) 


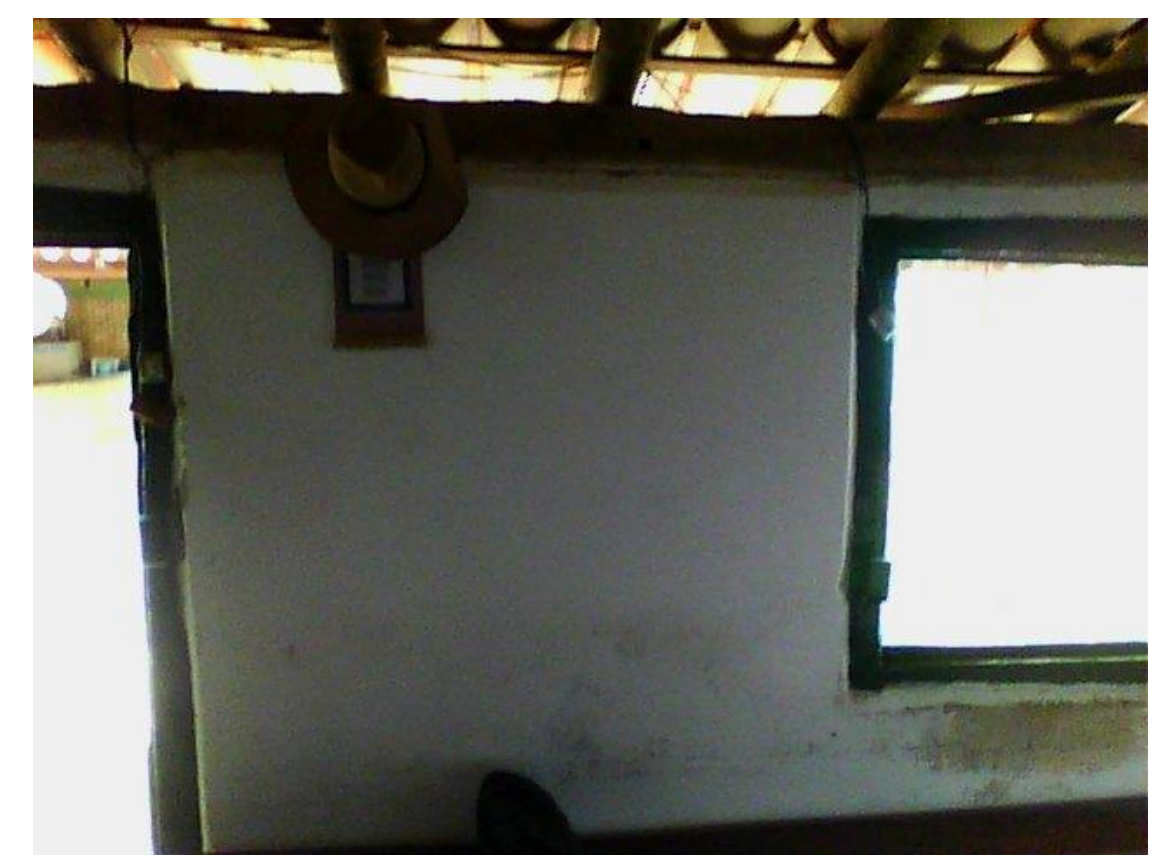

Figura 7- Parte interna da parede posterior. (Fonte: Própria)

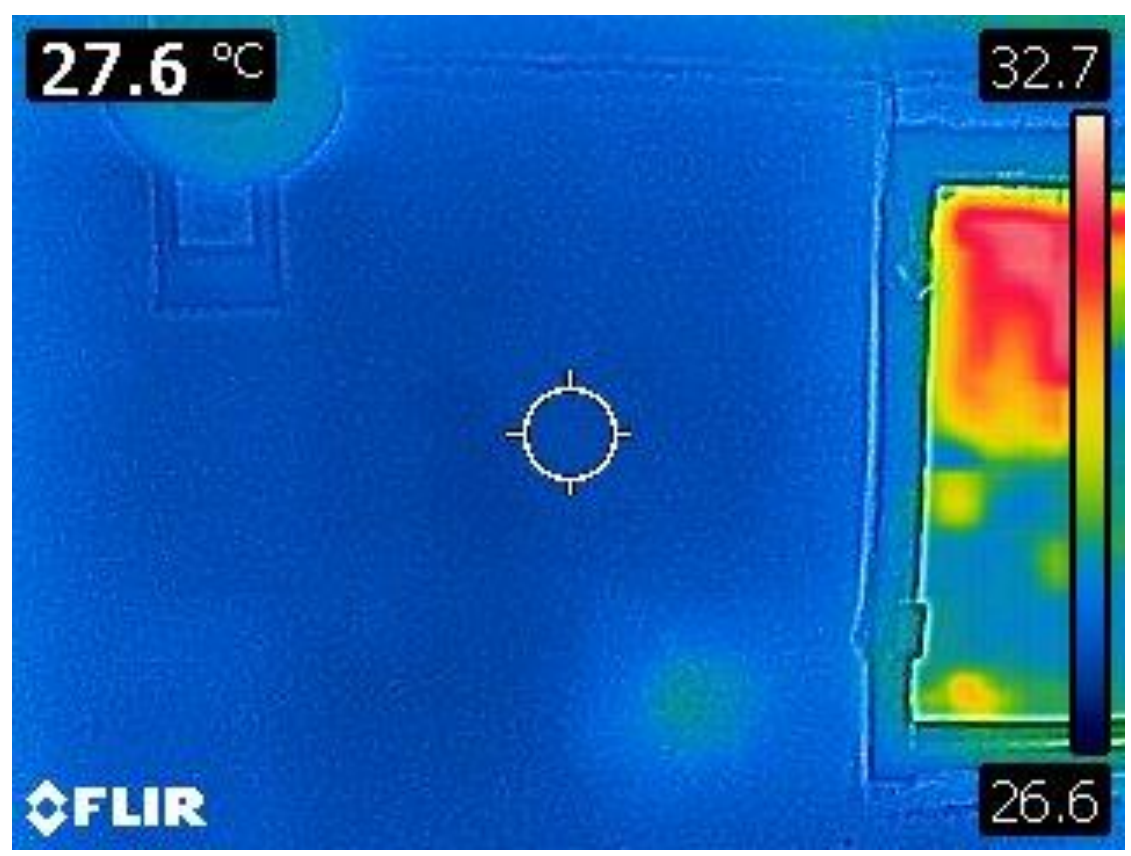

Figura 8- Parte interna da parede posterior, foto termográfica. (Fonte: Própria)

Ao comparar a mesma parede interna e externamente fica evidente a baixa condutividade térmica o que colabora com a baixa da temperatura interna em relação a externa.

Foi analisada também uma construção do programa de assistência a moradia vigente no DF (Concreto), Minha Casa Minha Vida, localizada no Paranoá Parque. 
Vale ressaltar que as condições de medidas foram aas mesmas da tipologia vernacular de forma que a variação da temperatura interna e externa não estava nos valores mais altos possíveis.

Essa tipologia possui a distribuição de áreas oposta a vernacular, os quartos possuem maior área quando comparados a área relativa a sala e cozinha.

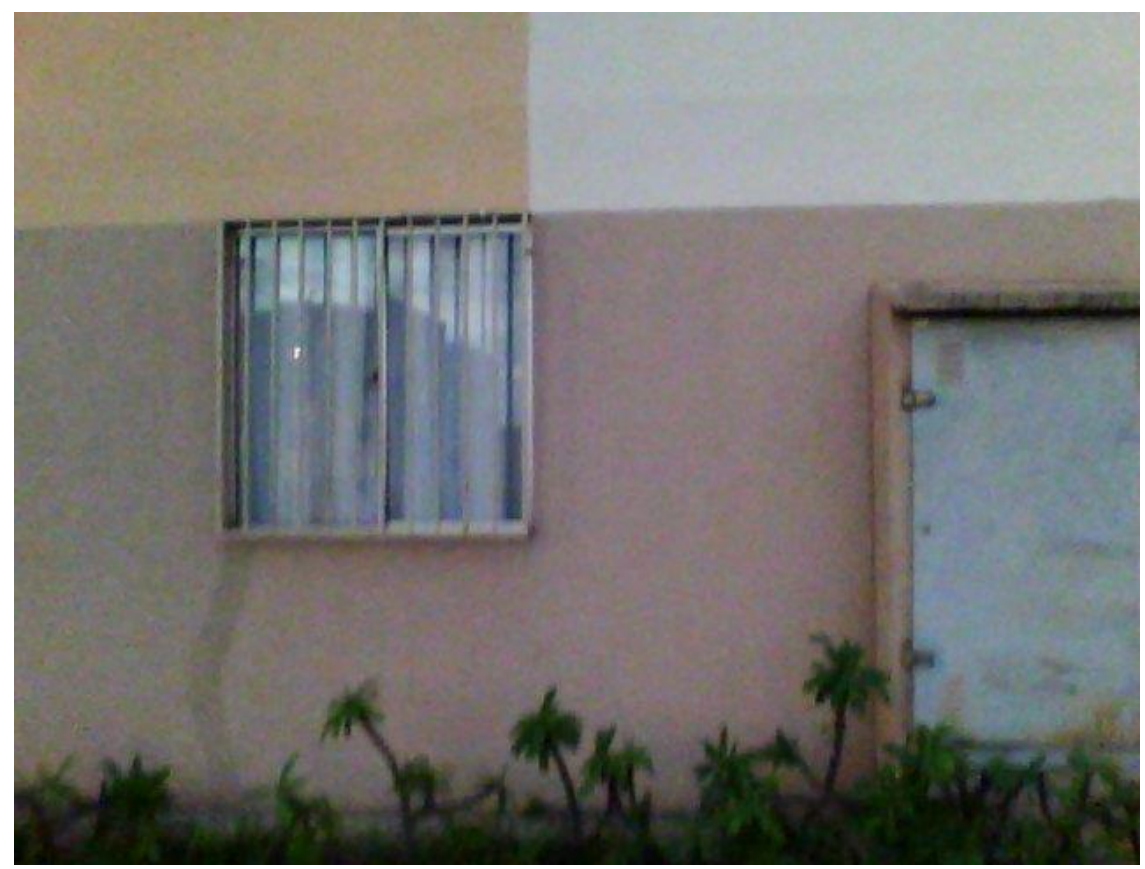

Figura 9- Parte externa da parede lateral. (Fonte: Própria)

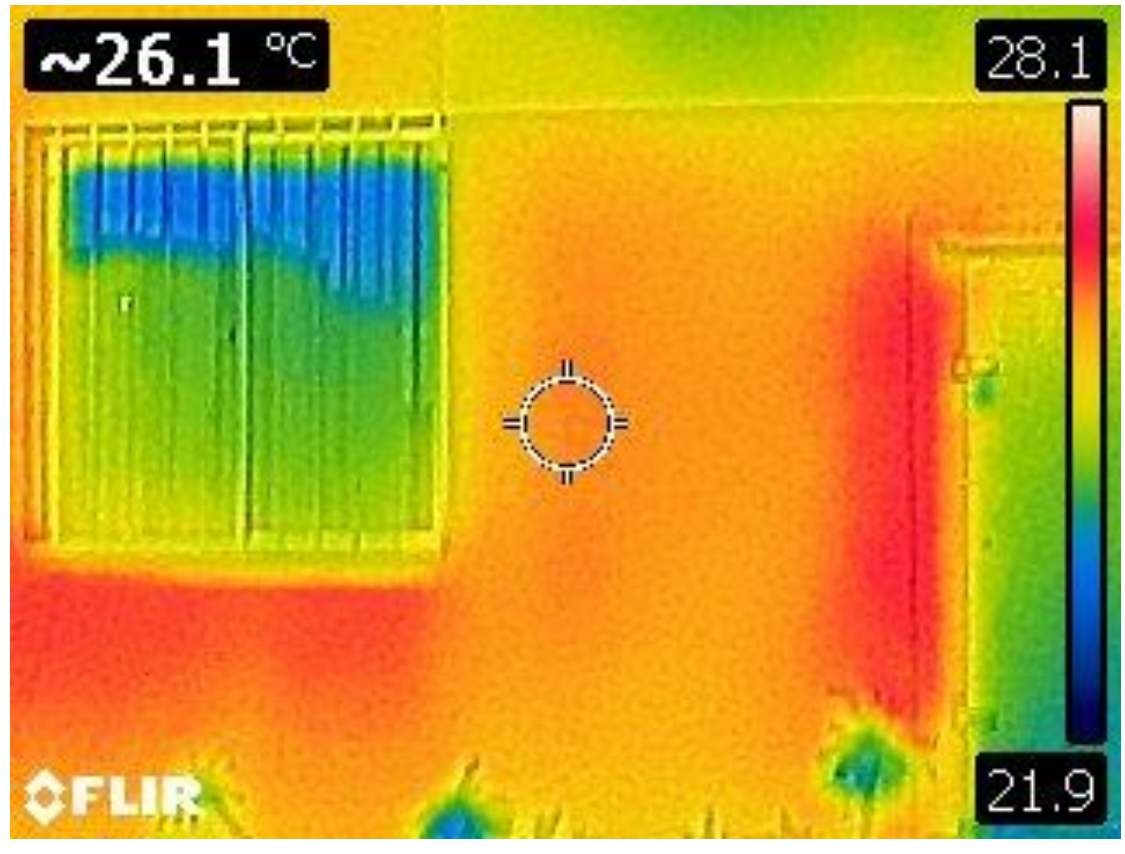

Figura 10- Parte externa da parede lateral, foto termografica. (Fonte: Própria) 


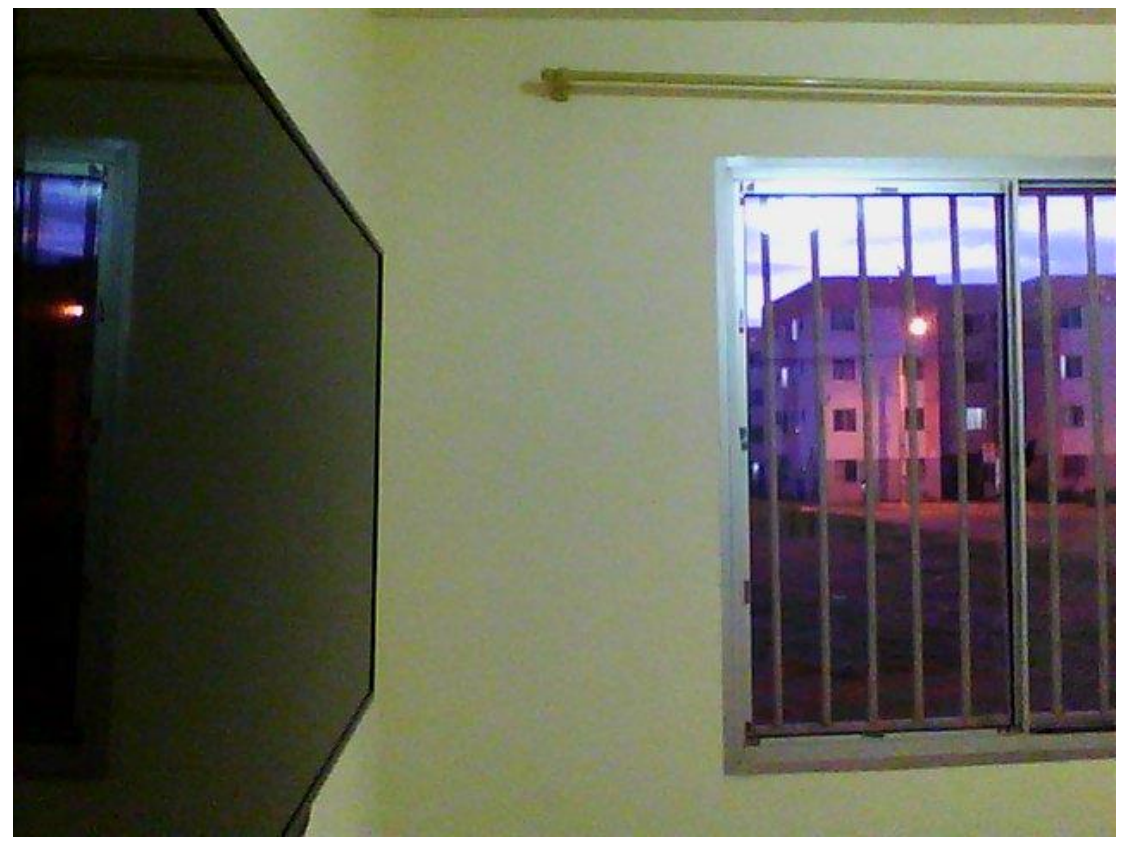

Figura 11- Parte interna da parede lateral. (Fonte: Própria)

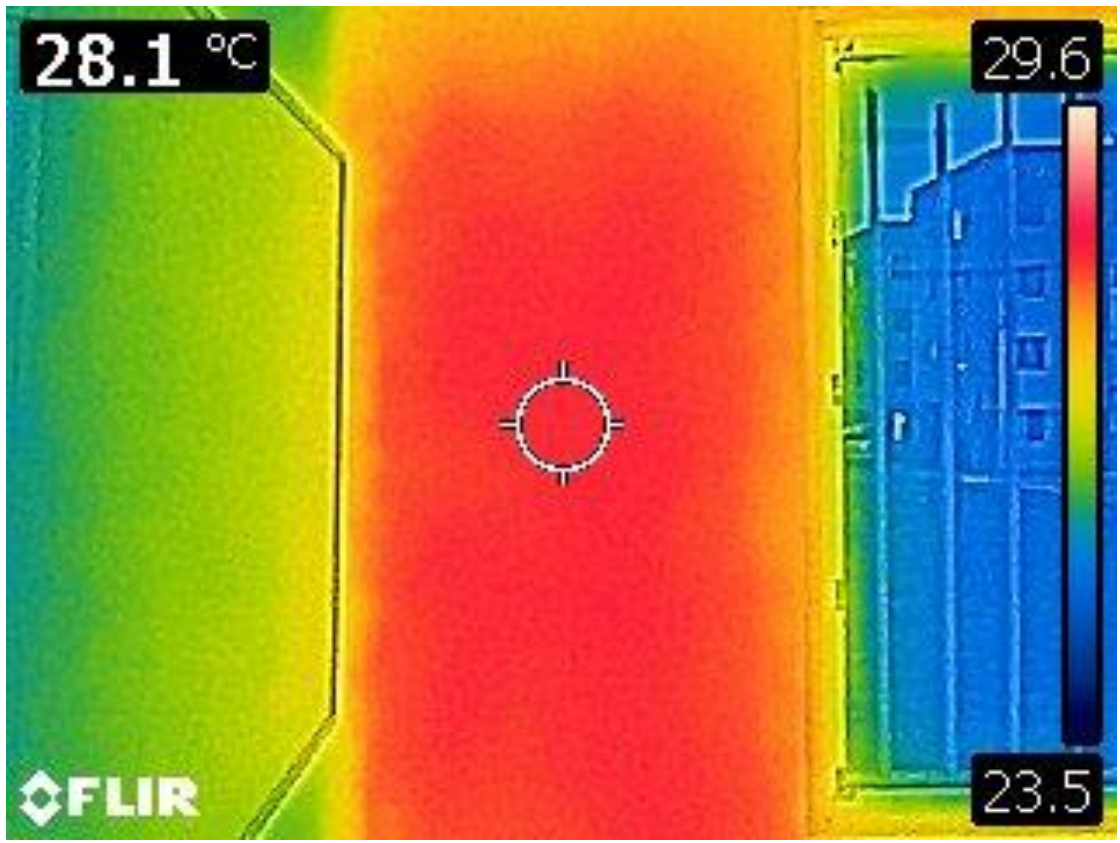

Figura 12 - Parte interna da parede lateral, foto termografica. (Fonte: Própria)

É possível observar pela comparação das duas superfícies da mesma parede que o comportamento térmico não é adequado de forma que a superfície interna apresenta $2 \mathrm{C}^{\circ}$ a mais que a superfície externa. 


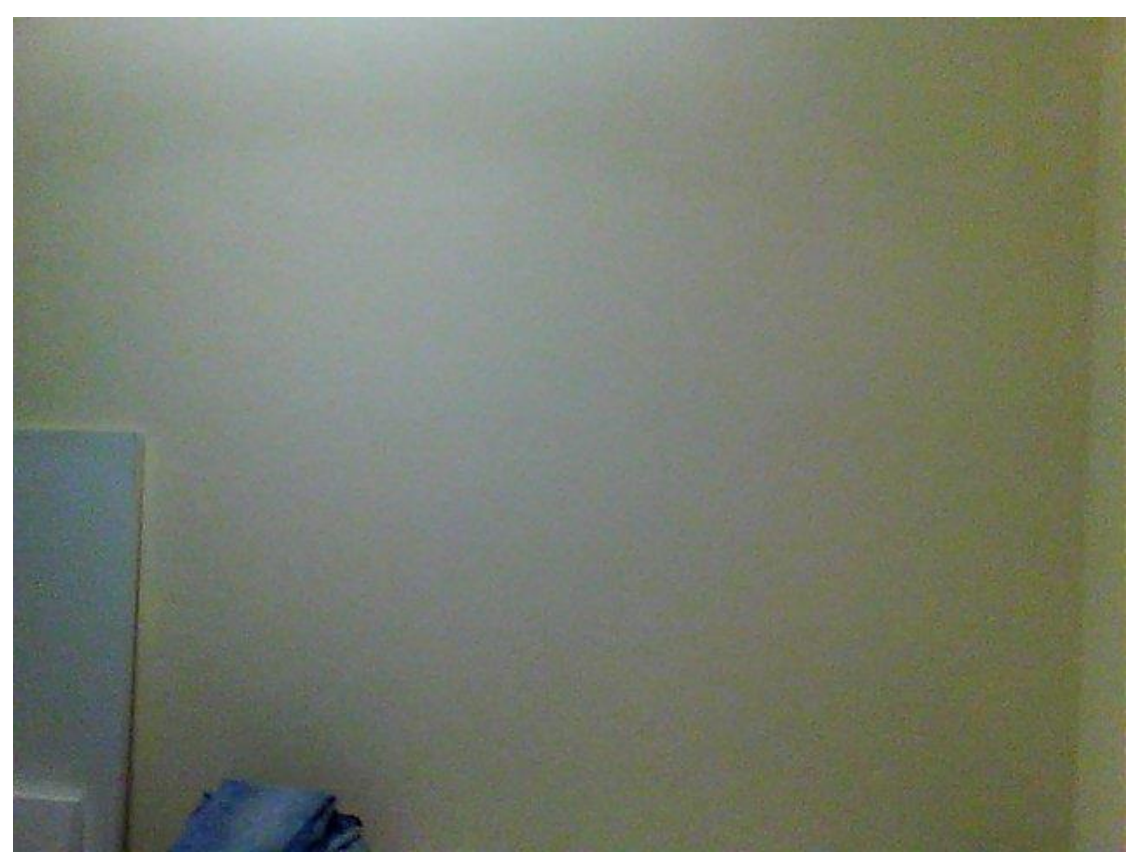

Figura 13- Parte interna da parede lateral em um cômodo sem abertura de esquadria nessa orientação. (Fonte: Própria)

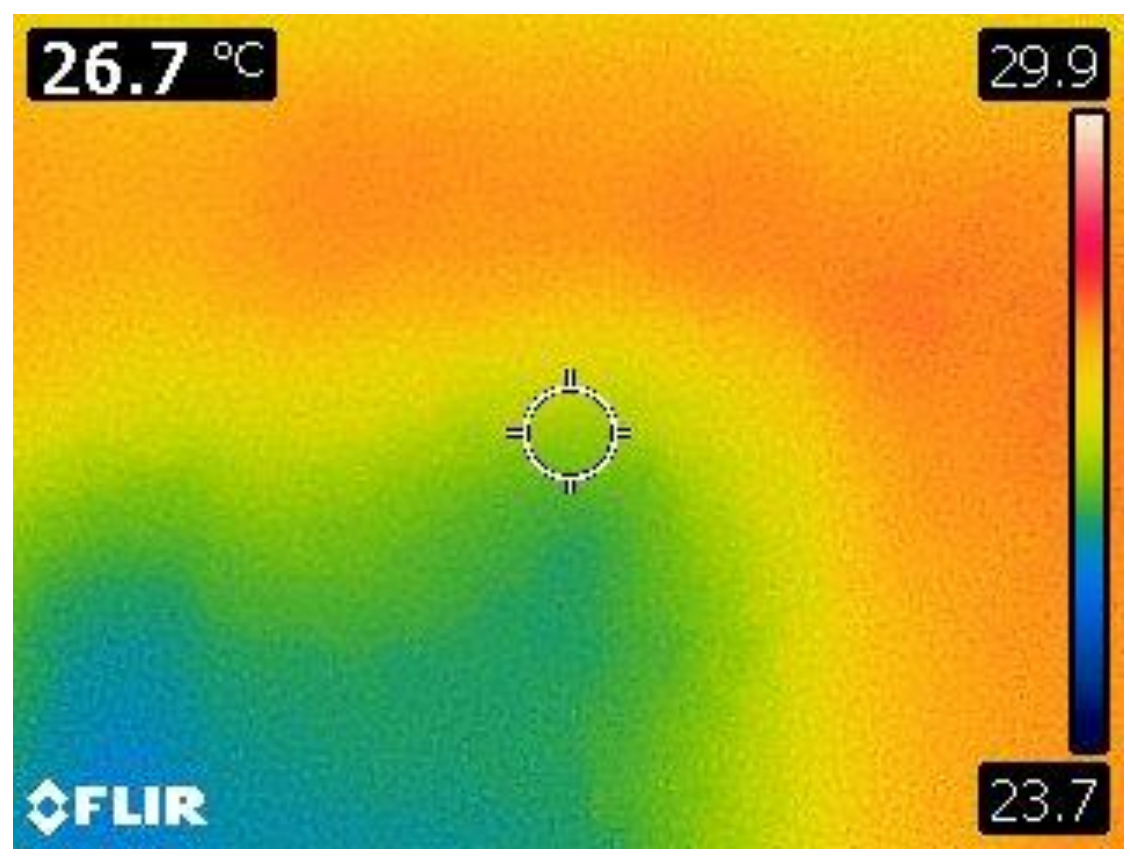

Figura 14- Parte interna da parede lateral em um cômodo sem abertura de esquadria nessa orientação, foto termográfica. (Fonte: Própria)

Ao analisarmos o cômodo que possui a mesma orientação ao anterior mas possui o diferencial da fachada na qual a abertura está localizada percebe-se que grande parte do desconforto térmico dessa edificação ocorre devido a implantação inadequada. 


\begin{tabular}{|l|c|c|}
\hline \multicolumn{1}{|c|}{ Medições } & Pau-a-Pique & Concreto \\
\hline Umidade interna & $55.8 \% \mathrm{RH}$ & $67 \% \mathrm{RH}$ \\
\hline Umidade externa & $55 \% \mathrm{RH}$ & $69 \% \mathrm{RH}$ \\
\hline Temperatura interna & $22.3 \mathrm{C}^{\circ}$ & $22 \mathrm{C}^{\circ}$ \\
\hline Temperatura externa & $22.5 \mathrm{C}^{\circ}$ & $20.4 \mathrm{C}^{\circ}$ \\
\hline Preço por $\mathbf{M}^{2}$ & $230 \mathrm{R} \$$ & $450 \mathrm{R} \$$ \\
\hline
\end{tabular}

O comparativo acima demostra que a arquitetura vernacular possui maiores vantagens sobre a tradicional, a umidade relativa do ar é mais alta na parte interna e a temperatura mais baixa, já a convencional demostra o oposto, a temperatura interna é mais que a externa e a umidade relativa do ar mais baixa. De forma que o conforto oferecido pela construção de Pau-a-Pique é mais significativo que o da construção de concreto, que demostra um desconforto considerável.

\section{Entrevistas}

\subsection{Entrevista com moradores da edificação vernacular}

A entrevista foi realizada com uma antiga moradora da fazenda que atualmente mora em uma casa de alvenaria convencional, ela passou a maior parte de sua infância na residência e até hoje passa temporadas na casa.

A razão pela mudança de não foi relacionada a qualidade técnica da residência, mas pelo fato de estar localizada distante de Brasília.

\section{Pra você como seria a casa perfeita?}

É uma casa que tem Funcionalidade e praticidade.

\section{Você está satisfeito com a sua casa?}

Atualmente moro em um apartamento de tijolo comum e infelizmente não estou satisfeita com a minha casa.

\section{Se você pudesse mudar uma coisa da sua casa o que mudaria?}

Aumentaria o tamanho dos quartos, tanto em meu apartamento quanto na fazenda, sendo que no meu apartamento o mais urgente seria aumentar o tamanho da cozinha.

Se você pudesse manter uma coisa da sua casa o que manteria?

O tamanho da cozinha da fazenda é ideal, quanto ao meu apartamento não manteria nada.

Qual o cômodo mais importante na sua casa?

A cozinha.

Sua casa é muito fria ou muito quente?

Minha casa atual é muito quente 
O barulho do rua te incomoda quando você está em casa?

Não, em nenhuma das residências sinto incomodo com o barulho.

Você esteve presente durante a construção da sua casa (da edificação vernácula?

Não era nascida na época de construção.

Você gostaria de ter estado envolvido na construção da sua casa (da edificação vernácula)?

Gostaria.

O que você teria feito de diferente se estivesse presente no processo de construção (da edificação vernácula)?

Teria feito um aumento considerável no tamanho dos quartos.

Como conheceu essa técnica de construção?

Conheci através do meu avô que sempre fez questão de nos contar a história de como essa casa foi construída no século XIX.

Você já conhecia alguém que morou em uma casa de terra

Sim, meus tios-avôs sempre moraram em casas assim.

É a primeira vez que você mora em uma casa de terra?

Sempre tive contato com essas construções, por conta da minha família.

Qual foi a técnica de construção usada na antiga casa?

Todas as casas que tive contato foram feitas de Pau-a-pique.

Como a sua casa antiga se compara com a casa nova?

Todas possuíam a mesma qualidade em questão da durabilidade e da funcionalidade, todas ainda estão de pé.

Você já morou em uma casa de tijolo comum?

Sim, moro atualmente.

Como sua casa antiga se compara com sua casa nova? 
Não se compara em nada a casa da fazenda tem uma durabilidade e funcionalidade muito maior.

5.2 Entrevista com os moradores do programa Minha Casa Minha Vida

A entrevista foi realizada com um morador atual da edificação do minha casa minha vida.

Pra você como seria a casa perfeita?

Uma casa confortável onde eu me sinta bem.

Você está satisfeito com a sua casa?

Sim, sempre agradeço a Deus por tê-la.

Se você pudesse mudar uma coisa da sua casa o que mudaria?

Teria quartos maiores.

Se você pudesse manter uma coisa da sua casa o que manteria?

As paredes de concreto que me transmitem segurança.

Qual o cômodo mais importante na sua casa?

A sala.

Sua casa é muito fria ou muito quente?

As vezes fica muito quente.

O barulho do rua te incomoda quando você está em casa?

Não incomoda, a acústica é muito boa.

Você esteve presente durante a construção da sua casa?

Fiz umas duas visitas na época dos acabamentos.

Você gostaria de ter estado envolvido na construção da sua casa?

Teria colocado um piso mais resistente, como um porcelanato, e box no chuveiro.

O que você teria feito de diferente se estivesse presente no processo de construção?

Teria colocado um piso mais resistente, como um porcelanato, e box no chuveiro. 


\section{Antes de morar em uma casa da minha casa minha vida o que pensava do projeto? \\ Pensei que fosse um projeto só para dar créditos aos políticos.}

\section{O que pensa sobre o projeto depois que se mudou?}

Gosto, me sinto confortável.

\section{CONSIDERAÇÕES FINAIS}

A pesquisa realizada buscou verificar a potencialidade da arquitetura vernácula na aplicação em projetos sociais em contraposição dos projetos existentes no Brasil na atualidade. Para isso foi feita uma análise bibliográfica extensa para entender melhor a história da habitação social no Brasil, as políticas atuais vigentes no Brasil e no DF sobre a habitação de interesse social, a temática da autoconstrução em terra crua e a adaptabilidade dessa construção às normas.

Foi escolhida a tipologia do adobe para a análise da adequação as normas por essa possuir maior presença em pesquisa acadêmicas e representar grande parte das construções de terra brasileiras, essa tipologia possui um conjunto de normas formais próximas a aprovação.

A pesquisa em loco foi realizada em uma casa centenária que demostrou a durabilidade da arquitetura de terra e exemplificou as vantagens térmicas e financeiras dessa tipologia. Quando comparada a tipologia analisada do Minha Casa Minha Vida ficou evidente a superioridade em relação ao âmbito social, cultural e formal.

As entrevistas demonstraram que embora as duas vertentes tenham muitas diferenças formais, ambos os moradores compartilham opiniões sobre as áreas mais importantes da casa e ambos corroboraram para as teses defendidas no estudo bibliográfico. A entrevista sobre a moradia popular demostrou alto nível de engajamento sociocultural e uma forte memória afetiva sobre a técnica. Já a entrevista sobre a moradia tradicional levantou um aspecto importante da cultura construtiva brasileira, a robustez da construção associada a nossa segurança física. Ambos pontos importantes e devem ser considerados na elaboração de construções que se adequem ao usuário.

Por meio dessa pesquisa concluiu-se que a arquitetura popular é uma opção válida para habitação de cunho social e seria de interesse mútuo do governo e do moradores trabalharem em parceria através da associação das técnicas de construção do saber popular e o financiamento dos cofres públicos. É necessário levar em consideração o caráter artesanal dessa tipologia e propor juntamente com profissionais soluções para a replicação dessas construções de forma que não perca a condição popular. Uma proposta interessante deve levar em consideração uma aliança tripla entre a população, os profissionais, e o governo. 


\section{REFERÊNCIAS}

Adobe, matéria-prima tão antiga, pode ser alternativa para o futuro- 2013https://casa.abril.com.br/casas-apartamentos/adobe-materia-prima-tao-antigapode-ser-alternativa-para-o-futuro/- em:2020

AMIRI, Niki e VATANDOOST, Mohammad Mehdi. The Study of the Relationship between Sustainable Architecture and Vernacular Architecture in the North of Iran, 2017.

ANNA, Marcia Sant'. Arquitetura Popular Espaço e Saberes, 2013.

ARTIGA, Vilanova. Os Caminhos da Arquitetura Moderna, 1954.

BAHADORI, Mehdi N.; HAGHIGHAT, Fariborz. Thermal performance of adobe structures with domed roofs and moist internal surfaces. Solar Energy.

BORTOLUCCI, José Henrique. A Descoberta do Viver Periférico, 2016.

BUNDUKI, Nabil. Origens da habitação social no Brasil, 1998.

FLORIM, L. C., Quelhas, O. L. G. Contribuição para a construção sustentável: características de um projeto habitacional eco-eficiente, 2004.

GUY, Simon; FARMER, Graham. Reinterpreting Sustainable Architecture: The Place of Technology. 2001

JACQUES, Paola Berenstein. Estética da ginga: a arquitetura das favelas através da obra de Hélio Oiticica. 2. ed. Rio de Janeiro: Casa da Palavra, 2003.

LARA, Fernado Luiz. Modernism Made Vernacular The Brazilian Case

LIMA JUNIOR, G. Perfil Tecnológico das Construções Praieiras do Nordeste do Brasil. 2013.

MARQUES, Luisa - Comportamento térmico do adobe, 2018.

NEVES, Claudete. Materiais e Técnicas Construtivas de Baixo Custo Para a Construção em Cabo Verde, 2014.

OLIVER, Paul. Built to meet needs: cultural issues in Vernacular Architecture. Oxford: Elsevier LTDA, 2006.

OLIVEIRA, Larissa Castro. Autoconstrução Como Tática Habitacional na Cidade Contemporânea. 2017

PIRES, Jhennyfer Loyane Gama. Desempenho Térmico em Habitações Unifamiliares de Interesse Social - Estudo de Caso em Planaltina/DF, 2018. 
PIRES, Juliana Pires. Estudo Comparativo dos Sistemas Construtivos na Construção de Habitações de Interesse Social Rural - ASPECTOS ENERGÉTICOS E ECONÔMICOS, 2014.

SANTORO, Renata Branca e PENTEADO, Claudio Luís de Camargo. Bioconstrução: Utilizando o Conhecimento Ecológico Para a Criação de Construções Saudáveis

SANTOS, Soraia Costa dos; COSTA, Silvia Kimo. Arquitetura vernacular ou popular brasileira: conceitos, aspectos construtivos e identidade cultural local, 2017.

SILVA, Sheina Suely de Vasconcelos. Arquitetura Sustentável: Em busca de lições nas técnicas construtivas vernaculares, 2017.

SZüCS, C. P.; Pereira, G. M.; Silva, C. S. F.; Costa, M. Sustentabilidade social e habitação social. In: IV Encontro Nacional e II Encontro Latino americano sobre Edificações e Comunidades Sustentáveis. Anais... Campo Grande: UFMS, 2007.

WCED Our common Future. Oxford: Oxford University Press, 1987.

WEIMER, Günter. Arquitetura popular brasileira. SÃO PAULO: Editora Martins fontes, 2012. 